\title{
Advances in the Diagnosis of Foot-and-Mouth Disease
}

\author{
Chuan Loo Wong ${ }^{1}$, Chean Yeah Yong ${ }^{1,2}$, Hui Kian Ong ${ }^{3}$, Kok Lian $\mathrm{Ho}^{3}$ and \\ Wen Siang $\operatorname{Tan}^{1,2 *}$
}

1 Department of Microbiology, Faculty of Biotechnology and Biomolecular Sciences, Universiti Putra Malaysia, Serdang, Malaysia, ${ }^{2}$ Laboratory of Vaccines and Biomolecules, Institute of Bioscience, Universiti Putra Malaysia, Serdang, Malaysia,

${ }^{3}$ Department of Pathology, Faculty of Medicine and Health Sciences, Universiti Putra Malaysia, Serdang, Malaysia

\section{OPEN ACCESS}

Edited by:

Mariano Pérez-Filgueira, National Agricultural Technology Institute, Argentina

Reviewed by:

Marie Rene Culhane,

College of Veterinary Medicine, University of Minnesota, United States Jitendra Kumar Biswal,

Indian Council of Agricultural

Research (ICAR), India

*Correspondence:

Wen Siang Tan

wstan@upm.edu.my

Specialty section:

This article was submitted to

Veterinary Infectious Diseases,

a section of the journal

Frontiers in Veterinary Science

Received: 24 March 2020

Accepted: 26 June 2020

Published: 21 August 2020

Citation:

Wong CL, Yong CY, Ong HK, Ho KL and Tan WS (2020) Advances in the

Diagnosis of Foot-and-Mouth

Disease. Front. Vet. Sci. 7:477.

doi: 10.3389/fvets.2020.00477
Foot-and-mouth disease (FMD) is a devastating livestock disease caused by foot-and-mouth disease virus (FMDV). Outbreaks of this disease in a country always result in conspicuous economic losses to livestock industry and subsequently lead to serious socioeconomic damages due to the immediate imposition of trade embargo. Rapid and accurate diagnoses are imperative to control this infectious virus. In the current review, enzyme-linked immunosorbent assay (ELISA)-based methods used in FMD diagnosis are extensively reviewed, particularly the sandwich, liquid-phase blocking, and solid-phase competition ELISA. The differentiation of infected animals from vaccinated animals using ELISA-based methods is also highlighted, in which the role of $3 A B C$ polyprotein as a marker is reviewed intensively. Recently, more studies are focusing on the molecular diagnostic methods, which detect the viral nucleic acids based on reverse transcription-polymerase chain reaction (RT-PCR) and RT-loop-mediated isothermal amplification (RT-LAMP). These methods are generally more sensitive because of their ability to amplify a minute amount of the viral nucleic acids. In this digital era, the RT-PCR and RT-LAMP are progressing toward the mobile versions, aiming for on-site FMDV diagnosis. Apart from RT-PCR and RT-LAMP, another diagnostic assay specifically designed for on-site diagnosis is the lateral flow immunochromatographic test strips. These test strips have some distinct advantages over other diagnostic methods, whereby the assay often does not require the aid of an external device, which greatly lowers the cost per test. In addition, the on-site diagnostic test can be easily performed by untrained personnel including farmers, and the results can be obtained in a few minutes. Lastly, the use of FMDV diagnostic assays for progressive control of the disease is also discussed critically.

\begin{abstract}
Keywords: foot-and-mouth disease virus (FMDV) diagnosis, complement fixation test (CFT), virus neutralization test (VNT), enzyme-linked immunosorbent assay (ELISA), reverse transcription-polymerase chain reaction (RT-PCR), reverse transcription-loop-mediated isothermal amplification (RT-LAMP), reverse transcriptionrecombinase polymerase amplification (RT-RPA), lateral flow device (LFD)
\end{abstract}

\section{INTRODUCTION}

Foot-and-mouth disease (FMD) is a contagious vesicular disease caused by foot-and-mouth disease virus (FMDV), a member of the Picornaviridae family. The virus infects a wide range of wild and domesticated cloven-footed mammals. An accidental introduction of FMDV in a susceptible population can result in an abrupt outbreak of the disease, leading to a massive economic loss. 
Immediate actions are usually taken in response to an FMD outbreak to secure a differential and definitive diagnosis and to prevent further spread of the disease (Figure 1). To complement the vaccination and stamping out policies, early FMD detections in cloven-hoofed animals using current available diagnostic tools have been widely employed to counter this highly scrutinized agent.
Generally, a suspected case of FMD can be identified based on observations of clinical signs. Severity of the symptoms in animals is affected by many factors, such as the species and age of the animals, virus strains, dosage of exposure to FMDV, and the host immunity. The symptoms are generally more severe in cattle and intensively reared swine (high-density indoor-rearing in straw-lined sheds or group-housing), as compared to goats

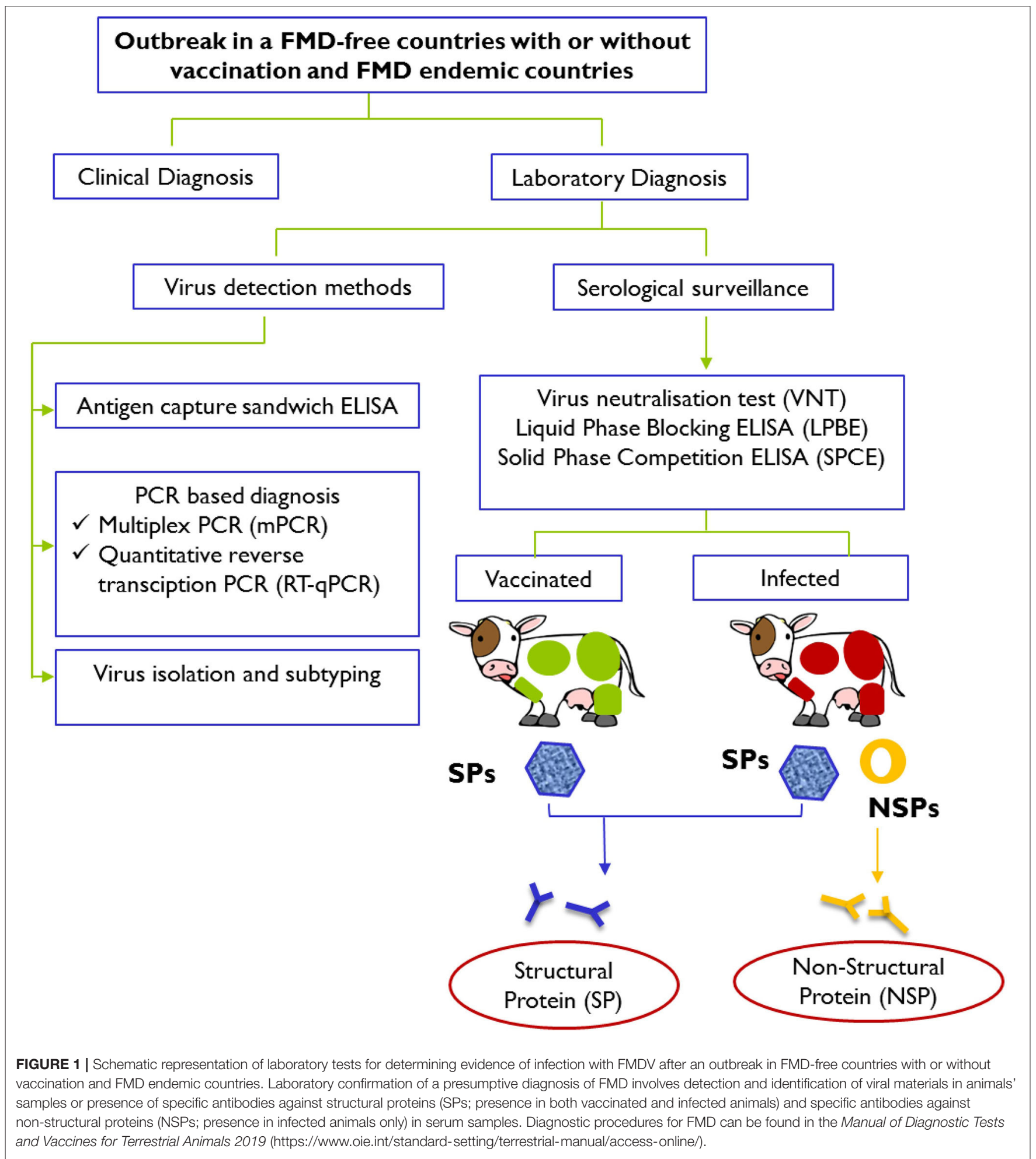


and sheep $(1,2)$. Typically, FMDV-infected animals will develop lesions on the tongue, muzzle, oral cavity, coronary bands, and teats. Other symptoms frequently observed include fever, loss of appetite, weight loss, hypersalivation, depression, growth retardation, and severe decrease in milk production, which could persist after recovery (2). However, diagnoses based on clinical symptoms are highly unreliable, because several other diseases share similar symptoms as FMD, which include swine vesicular disease (SVD), vesicular stomatitis and vesicular exanthema. Swine are vulnerable to vesicular stomatitis, SVD, and FMD, whereas cattle are vulnerable to vesicular stomatitis and FMD, all of which could not be distinguished based on clinical symptoms (3-5). Hence, confirmatory laboratory diagnosis of any suspected FMD case is vital.

Conventional techniques such as complement fixation test (CFT), virus isolation test, virus neutralization test (VNT), and enzyme-linked immunosorbent assay (ELISA) are routinely used to detect FMDV in clinical samples. As virus isolation tests, CFT and VNT are well-established and often used as standards in development of new detection assays; thus, they will not be discussed in detail in this article. Advancement in molecular techniques accelerates rapid and accurate diagnoses of FMDV through detection of the viral RNA. In this article, the most recent advancements in reverse transcription-polymerase chain reaction (RT-PCR) and RTloop-mediated isothermal amplification (RT-LAMP)-based methods are thoroughly reviewed. Lastly, the roles of lateral flow immunochromatographic (LFI) test strips in FMDV diagnosis are also discussed.

\section{NUCLEIC ACID DETECTION METHODS}

Nucleic acid detection methods are molecular-based techniques used to detect the presence of viral nucleic acids. As these methods involve amplifications of viral nucleic acids, they have higher sensitivity compared to serological methods. In addition to detection of FMDV, primers used for FMDV serotyping have also been developed (6). As FMDV is an RNA virus, RT is required before the targeted viral nucleic acid can be amplified. Two of the most common nucleic acid detection methods used to detect FMDV are RT-PCR and RT-LAMP. Although the detection and typing of FMDV using microarray was also reported (7-9), its usage is highly limited, possibly due to the high operating cost. Table 1 summarizes some recent studies on molecular diagnostic assays for the detection of FMDV.

\section{Reverse Transcription-Polymerase Chain Reaction}

Detection of FMDV using RT-PCR was first reported by Meyer et al. (32), in which a conserved region in the viral genome encoding the RNA polymerase was amplified and analyzed using agarose gel electrophoresis and further confirmed by restriction enzyme digestion or Southern blotting. Höfner et al. (33) also demonstrated the detection of FMDV in clinical samples using primers targeting the $1 \mathrm{~A}$ and $2 \mathrm{~A} / 2 \mathrm{~B}$ conserved regions, amplifying the whole viral capsid coding region. Nucleotide sequencing of the amplified region can directly aid in the study of viral epidemiology. In a separate study, Laor et al. (34) showed that the primers targeting the RNA polymerase coding region could detect FMDV of different isolates, whereas another primer set targeting the variable region of VP1 was capable of differentiation detection. Dill et al. (10) developed a universal RT-PCR, which is rapid and cost-effective in generating the genome sequences of all FMDV serotypes, allowing immediate virus genotyping, phylogenetic analysis, and epidemiological studies of FMDV. Most recently, a primer set, namely, FM8/9, which targets the conserved region of $3 \mathrm{D}$ domain has also been reported to be $10^{0.6}$ - to $10^{3.8}$-fold more sensitive than the $1 \mathrm{~F} / \mathrm{R}$ primer set as suggested in the OIE manual (11).These agarose gel electrophoresis-based methods have since laid the basis for the modern RT-PCR and RT-LAMP detection methods.

To date, many improved versions of RT-PCR have been employed for the detection of FMDV. To simultaneously screen for the presence of multiple viruses, multiplex RT-PCR, which uses multiple primer sets in a single reaction, has been developed. Lung et al. (9) demonstrated the use of multiplex RT-PCR for simultaneous detection and differentiation of FMDV serotypes and other vesicular disease viruses, including vesicular stomatitis virus (VSV), swine vesicular disease virus (SVDV), and vesicular exanthema of swine virus (VESV). When the multiplex RTPCR is used in conjunction with slide microarray, the sensitivity improved by at least one log unit. However, the sensitivity was reported to be comparable but no better than real-time RT-PCR (RT-qPCR). Similarly, Erickson et al. (22) also used multiplex RT-PCR coupled with a more advanced, automated electronic microarray assay for simultaneous detection and differentiation of several swine viruses, including FMDV and other viruses such as SVDV, African swine fever virus, porcine circovirus type 2, porcine respiratory and reproductive syndrome virus, VESV, and classical swine fever virus. Although it is convenient to detect multiple viruses of different serotypes in a single reaction, careful design, and testing of primers are needed to achieve desirable assay sensitivity and specificity, as multiplex RT-PCR assays have been reported to have better sensitivity upon removal of certain primers from the pool (22).

Real-time quantitative PCR (qPCR)-based analyses coupled with fluorescent-emitting compounds have been used to measure the number of amplicons during an amplification process in real time (35). Generally, there are two types of fluorescentemitting compounds used in qPCR: (i) non-specific intercalating dye such as SYBR green and (ii) specific reporter probes with fluorochromes attached to specific oligonucleotide sequences, such as fluorescence resonance energy transfer (FRET) and Taqman probes. These compounds have been used in RTqPCR for detection of FMDV [FRET- (36); TaqMan- (37, 38); SYBR green- RT-qPCR $(17,39)]$. While SYBR green is more economic, TaqMan and FRET probes have the advantage as signals generated from unspecific PCR are negligible. The most common target sequences for the detection of FMDV with RT-qPCR include 3D and 5' UTR sequences $(37,38)$, in which the addition of $5^{\prime}$-tails to the primers targeting $3 \mathrm{D}$ and $5^{\prime}$ UTR sequences was reported to enhance the detection of FMDV (16). As in RT-PCR, RT-qPCR has also been 
TABLE 1 | Molecular diagnostic assays for detection of FMDV infection.

\begin{tabular}{|c|c|c|c|c|}
\hline Methods & Description & Detection limit & $\begin{array}{l}\text { Tested clinical } \\
\text { samples }\end{array}$ & References \\
\hline \multirow[t]{2}{*}{ RT-PCR } & $\begin{array}{l}\text { Amplification of genome fragments from IRES to the end of } \\
\text { the ORF, followed by the Sanger sequencing for serotyping }\end{array}$ & $\begin{array}{l}\text { - } 5 \log _{10} \\
\text { dilution of viral RNA of } \\
\text { FMDV O/MOG/7/2010 }\end{array}$ & $\begin{array}{l}\text { Bovine saliva, porcine } \\
\text { podal vesicle, ovine } \\
\text { saliva, caprine serum } \\
\text { samples }\end{array}$ & (10) \\
\hline & $\begin{array}{l}\text { An RT-PCR based on a novel primer (FM8/9) targeting the 3D } \\
\text { region of the FMDV }\end{array}$ & $\begin{array}{l}\text { - } 10^{0.2} \text { to } 10^{-2.8} \\
\mathrm{TCID}_{50} / \mathrm{mL} \text { of FMDV } \\
\text { depending on } \\
\text { the strains }\end{array}$ & $\begin{array}{l}\text { Serum, and saliva } \\
\text { samples from pigs and } \\
\text { cows }\end{array}$ & (11) \\
\hline RT-iiPCR & $\begin{array}{l}\text { Utilizes a commercially available compact, portable } \\
\text { POCKITM Nuclei Acid Analyser (GeneReach, USA) for rapid } \\
\text { (<2 h) detection of all seven serotypes of FMDV. Coupling to } \\
\text { the taco }{ }^{\text {TM }} \text { mini extraction kit (GeneReach, USA), the } \\
\text { detection assay detected } 63 \text { different FMDV strains } \\
\text { representing all seven serotypes. Detection of the FMDV RNA } \\
\text { from vesicular fluid samples is possible without nuclei acid } \\
\text { extraction }\end{array}$ & $\begin{array}{l}\text { - } \geq 9 \text { copies of } \\
\text { in vitro-transcribed } \\
\text { FMDV O1 Manisa/69 } \\
\text { 3D RNA }\end{array}$ & $\begin{array}{l}\text { Nasal and oral swabs } \\
\text { from calves, sheep, } \\
\text { and piglets, oral fluid, } \\
\text { epithelial tissues, and } \\
\text { vesicular fluids from } \\
\text { piglets }\end{array}$ & (12) \\
\hline RT-ddPCR & $\begin{array}{l}\text { Targets FMDV 3D region based on the water-oil emulsion } \\
\text { droplet technology for partition of nanoliter droplets } \\
\text { containing viral cDNA. This assay enables absolute } \\
\text { quantification of the FMDV RNA without the need of reference } \\
\text { standards. Detects serotypes O, A, and C }\end{array}$ & $\begin{array}{l}\text { - } 10^{1.4} \mathrm{TCID}_{50} / \mathrm{mL} \text { and } \\
26.5 \text { copies of viral } \\
\text { RNA determined } \\
\text { using FMDV A24 } \\
\text { Cruzeiro and a } \\
\text { plasmid containing } \\
\text { the 3D-FMDV } \\
\text { sequences, respectively }\end{array}$ & $\begin{array}{l}\text { Epithelium and } \\
\text { esophageal- } \\
\text { pharyngeal fluids of } \\
\text { bovine origin }\end{array}$ & (13) \\
\hline RT-RPA & $\begin{array}{l}\text { An assay based on isothermal DNA amplification and the use } \\
\text { of combinatory enzymes and proteins. The assay was } \\
\text { reported to detect 3D RNA of FMDV within 4-10 min }\end{array}$ & $\begin{array}{l}\text { - 1,436 copies of } \\
\text { in vitro-transcribed } \\
\text { FMDV 3D RNA } \\
\text { - Diagnostic } \\
\text { sensitivity: } 98 \%\end{array}$ & $\begin{array}{l}\text { Heart, blood, serum, } \\
\text { milk, saliva, and } \\
\text { vesicular samples from } \\
\text { cattle, buffaloes, and } \\
\text { sheep }\end{array}$ & (14) \\
\hline \multirow{3}{*}{ RT-qPCR } & $\begin{array}{l}\text { Addition of } 5^{\prime} \text {-tails to the primers targeting } 3 D \text { and } 5^{\prime} \text { UTR } \\
\text { region of FMDV was demonstrated to enhance detection of } \\
\text { FMDV. The RT-qPCRs using the tailed forward and reverse } \\
\text { primers targeting 3D and } 5^{\prime} \text { UTR were performed in parallel in } \\
\text { a triplex one-step protocol. Both assays detected all seven } \\
\text { serotypes of FMDV with enhanced overall performance }\end{array}$ & $\begin{array}{l}\text { - The detection limit of } \\
\text { RT-qPCR (with tailed } \\
\text { primers) targeting 3D } \\
\text { and } 5^{\prime} \text { UTR of FMDV } \\
\text { are }-0.72 \text { and }-0.35 \\
\log _{10} \mathrm{TCID}_{50} / \mathrm{mL} \text { of } \\
\text { FMDV O1 } \\
\text { Manisa, respectively }\end{array}$ & $\begin{array}{l}\text { Serum samples from } \\
\text { cattle, pigs, and sheep }\end{array}$ & (16) \\
\hline & $\begin{array}{l}\text { An RT-qPCR assay based on the SYBR green I dye for } \\
\text { detection of FMDV of all seven serotypes. Primers used in this } \\
\text { assay were carefully selected using multiple in silico } \\
\text { approaches to enhance amplification efficiency }\end{array}$ & $\begin{array}{l}\text { - } 1-10 \text { copies/ } \mu L \text { of } \\
\text { in vitro-transcribed } \\
\text { FMDV RNA } \\
\text { depending on the } \\
\text { target regions }\end{array}$ & $\begin{array}{l}\text { Epithelium and } \\
\text { vesicular fluid samples } \\
\text { from cattle }\end{array}$ & (17) \\
\hline & $\begin{array}{l}\text { A pen-side, fully automated diagnostic tool (Enigma } \\
\text { MiniLab®) which integrate both nucleic acid extraction and } \\
\text { downstream RT-qPCR for rapid detection ( }<1.5 \mathrm{~h} \text { ) of FMDV. } \\
\text { The assay was shown to produced comparable results to the } \\
\text { standard RT-qPCR assay recommended by the OIE }\end{array}$ & $\begin{array}{l}\text { - } 10^{-5} \text { to } 10^{-6} \text { dilution } \\
\text { of the FMDV O/UAE } \\
2 / 2003 \text { stock } \\
\text { depending on the } \\
\text { nuclei acid } \\
\text { extraction kits. }\end{array}$ & $\begin{array}{l}\text { Saliva and epithelium of } \\
\text { bovine, porcine, and } \\
\text { ovine origin. Milk (from } \\
\text { bovine) spiked with } \\
\text { FMDV }\end{array}$ & (18) \\
\hline
\end{tabular}


TABLE 1 | Continued

\begin{tabular}{|c|c|c|c|c|}
\hline Methods & Description & Detection limit & $\begin{array}{l}\text { Tested clinical } \\
\text { samples }\end{array}$ & References \\
\hline & $\begin{array}{l}\text { A field-deployable RT-qPCR-based diagnostic system } \\
\text { (Biomeme two3 }{ }^{\text {TM }} \text { ) with Biomeme proprietary nucleic acid } \\
\text { extraction kit (M1) for rapid detection of FMDV, within } \\
30-60 \text { min. This system was reported to detect isolates } \\
\text { representing six serotypes (O, A, Asia 1, SAT 1, SAT 2, and } \\
\text { SAT 3) of FMDV. Detection of FMDV RNA in various samples } \\
\text { was possible without nucleic acid extraction steps, but at } \\
\text { lower sensitivity }\end{array}$ & $\begin{array}{l}\text { 10-4, } 10^{-3}, 10^{-2}, \\
10^{-5}, 10^{-3} \text {, and } \\
10^{-3} \text { dilutions of } \\
\text { FMDV O, A, Asia 1, } \\
\text { SAT 1, SAT 2, and } \\
\text { SAT } 3 \\
\text { stocks, respectively }\end{array}$ & $\begin{array}{l}\text { Serum, vesicular fluid, } \\
\text { tissue suspension, oral } \\
\text { fluid, oral, and nasal } \\
\text { swab samples from } \\
\text { sheep, pigs, and cattle }\end{array}$ & (19) \\
\hline & $\begin{array}{l}\text { This study compared the performance of two commercially } \\
\text { available one step RT-qPCR systems, TaqMan® Fast Virus } \\
\text { 1-Step Master Mix (Applied Biosystems } ® \text { ) and Superscript III } \\
\text { Platinum } ® \text { One-Step qRT-PCR Kit (Invitrogen }{ }^{T M} \text { ) in detection } \\
\text { of FMDV RNA from milk samples, a non-invasive alternative } \\
\text { for detection and typing of FMDV }\end{array}$ & $\begin{array}{l}\text { - The detection limit of } \\
\text { Superscript III } \\
\text { Platinum® One-Step } \\
\text { qRT-PCR Kit and } \\
\text { TaqMan® Fast Virus } \\
\text { 1-Step Master Mix } \\
\text { are } 10^{-6} \text { and } 10^{-5} \\
\text { dilutions of FMDV } \\
\text { A/KEN/6/2012, } \\
\text { respectively }\end{array}$ & $\begin{array}{l}\text { Serum, milk, vesicular } \\
\text { epithelium or fluid } \\
\text { samples of bovine } \\
\text { origin }\end{array}$ & $(20,21)$ \\
\hline
\end{tabular}

\section{RT-PCR-}

Microarray
This assay was capable of detecting and serotyping FMDV and VSV in addition to detecting VESV and SVDV. Multiplex RT-PCR was able to detect viruses representing all seven serotypes of FMDV. Typing of the FMDV was achieved by slide microarray containing serotype-specific probe
- The detection limit of multiplex RT-PCR and microarray are 46 and 4.6 $\mathrm{TCID}_{50} / \mathrm{mL}$ of FMDV O1 Manisa, respectively

- The diagnostic sensitivity and specificity: 92.6 and $100 \%$, respectively

This assay detects and differentiates FMDV, SVDV, VESV, ASFV, CSFV, PRRSV, and PCV2. Samples are amplified with multiplex RT-PCR and then applied to automated electronic microarray assay. This approach is less laborious and utilizes a single instrument that integrates and automates capture probe printing, hybridization, washing, and reporting on a disposable electronic microarray cartridge
- The detection limits of multiplex (seven-plex) RT-PCR and microarray for ASFV, PCV2 and PRRSV were reported to be at a range between one copy in PCR and 10 copies in microarray, respectively, followed by SVDV, CSFV and VESV at approximately 10 copies in PCR and 100 copies in microarray and $>100$ copies for FMDV in PCR and $>10,000$ copies in microarray
Oral swabs from calves serum, with viruses,

oral swabs from pigs

\begin{tabular}{|c|c|c|c|c|}
\hline \multirow[t]{2}{*}{ RT-LAMP } & $\begin{array}{l}\text { An assay for rapid detection (within } 45 \mathrm{~min} \text { ) and typing of } \\
\text { FMDV of serotype Asia } 1 . \text { This assay targets the conserved } \\
\text { region of VP1 sequence of FMDV serotype Asia } 1\end{array}$ & - NA & $\begin{array}{l}\text { Infected pig samples } \\
\text { (not specified) }\end{array}$ & (23) \\
\hline & $\begin{array}{l}\text { An assay for rapid detection and typing of FMDV of serotype } \\
\text { C. This assay targets the conserved region of VP1 sequence } \\
\text { of FMDV serotype C and can be completed in an hour }\end{array}$ & $\begin{array}{l}\text { - } 0.325 \mathrm{ng} / \mathrm{mL} \text { RNA } \\
\text { template harvested } \\
\text { from cell culture } \\
\text { infected with FMDV } \\
\text { of serotype C }\end{array}$ & $\begin{array}{l}\text { Infected cells and blood } \\
\text { samples from animals }\end{array}$ & (24) \\
\hline
\end{tabular}


TABLE 1 | Continued

\begin{tabular}{|c|c|c|c|c|}
\hline Methods & Description & Detection limit & $\begin{array}{l}\text { Tested clinical } \\
\text { samples }\end{array}$ & References \\
\hline & $\begin{array}{l}\text { A multiplex RT-LAMP assay that utilizes combined primer sets } \\
\text { from different individual RT-LAMP assays to compensate high } \\
\text { sequence variability of FMDV. The assay was demonstrated to } \\
\text { be superior or at least as good as individual RT-LAMP assay }\end{array}$ & $\begin{array}{l}\text { Detection limit: } 10^{-3} \\
\text { dilution of RNA } \\
\text { template harvested } \\
\text { from FMDV O1 } \\
\text { Manisa TUR/8/69 } \\
\text { infected epithelial } \\
\text { suspensions } \\
\text { - Diagnostic sensitivity } \\
\text { and specificity: } 98.0 \\
\text { and } \\
\text { 98.1\%, respectively }\end{array}$ & $\begin{array}{l}\text { Epithelial suspension } \\
\text { and esophageal- } \\
\text { pharyngeal fluid } \\
\text { samples from animals }\end{array}$ & (25) \\
\hline & $\begin{array}{l}\text { RT-LAMP assay utilizes swarm primers in addition to the } \\
\text { standard six primers for improved sensitivity. This assay was } \\
\text { demonstrated to specifically detect VP3 gene of FMDV (O } \\
\text { serotype) }\end{array}$ & 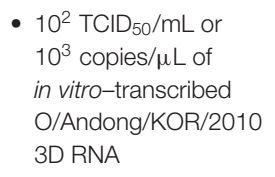 & $\begin{array}{l}\text { Serum, saliva, and } \\
\text { epithelial tissue } \\
\text { samples from animals }\end{array}$ & $(26)$ \\
\hline & $\begin{array}{l}\text { A real-time RT-LAMP assay targeting the 3D region for rapid } \\
\text { detection of FMDV serotypes } A, O \text {, and Asia 1. It uses } \\
\text { hydroxyl naphthol blue (HNB) dye for visual detection of } \\
\text { positive sample in addition to the turbidity change }\end{array}$ & $\begin{array}{l}4.2 \times 10^{-4}, 2 \times \\
10^{-6} \text { and } 1.1 \times 10^{-4} \\
\mathrm{TCID}_{50} / \mathrm{mL} \text { for FMDV } \\
\text { serotypes } \mathrm{O}, \mathrm{A} \text { and } \\
\text { Asia1, respectively }\end{array}$ & $\begin{array}{l}\text { Tongue epithelium and } \\
\text { semen samples from } \\
\text { infected bulls }\end{array}$ & $(27)$ \\
\hline & $\begin{array}{l}\text { The study evaluated RT-LAMP assay that utilized lyophilized } \\
\text { reagents for detection of FMDV. Lyophilized reagents were } \\
\text { shown to have no negative impact on amplification }\end{array}$ & $\begin{array}{l}10 \text { copies/ } \mu \mathrm{L} \text { of } \\
\text { in vitro-transcribed } \\
\text { O/UKG/35/2001 } \\
\text { 3D RNA }\end{array}$ & $\begin{array}{l}\text { Epithelial tissue, serum, } \\
\text { and esophageal- } \\
\text { pharyngeal fluid } \\
\text { samples of bovine } \\
\text { origin }\end{array}$ & (28) \\
\hline & $\begin{array}{l}\text { An RT-LAMP assay targeting the 3D region for rapid detection } \\
\text { of FMDV. This assay targets the VP1 region of FMDV for } \\
\text { specific detection of FMDV serotypes } A, O \text {, and Asia } 1\end{array}$ & - 10 copies of DNA & NA & (29) \\
\hline Ag-RT-LAMP & $\begin{array}{l}\text { An assay that utilizes FMDV genotype-specific lgG } \\
\text { immobilized on a tube to capture the virus prior to RT-LAMP } \\
\text { amplification. The assay can be completed within } 3 \mathrm{~h} \text { but was } \\
\text { negatively affected by high viral load in the samples }\end{array}$ & $\begin{array}{l}\text { - } 0.58 \times 10^{2} \text { copies of } \\
\text { FMDV O/Akesu/58 }\end{array}$ & $\begin{array}{l}\text { Vesicle fluid samples } \\
\text { from cattle }\end{array}$ & (30) \\
\hline qRT-LAMP & $\begin{array}{l}\text { A real time RT-LAMP assay targeting the 3D region for rapid } \\
\text { detection of FMDV. This assay also targets the VP1 region of } \\
\text { FMDV for specific detection of FMDV serotypes } A, O \text {, and } \\
\text { Asia } 1\end{array}$ & $\begin{array}{l}\text { - } 10^{-5} \text { dilution of } \\
\text { FMDV RNA template } \\
\text { harvested from } \\
\text { infected epithelial } \\
\text { suspensions } \\
\text { - The detection limits } \\
\text { of FMDV serotypes } \\
\text { Asia } 1 \text { and } \mathrm{O} \text { is } 10^{-3} \\
\text { TCID } 50 / \mathrm{mL} \text {, and } \\
10^{-5} \mathrm{TCID}_{50} / \mathrm{mL} \text { for } \\
\text { serotype A }\end{array}$ & $\begin{array}{l}\text { Epithelial suspension, } \\
\text { tongue, and foot } \\
\text { epithelium from animals }\end{array}$ & $(29,31)$ \\
\hline
\end{tabular}

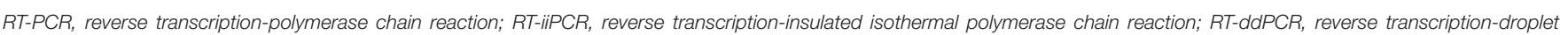

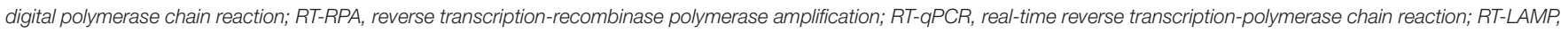

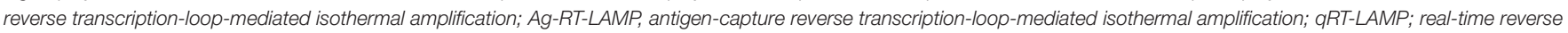

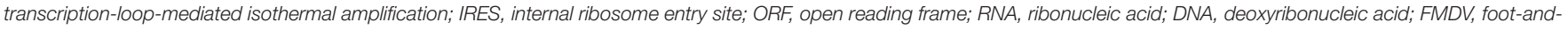

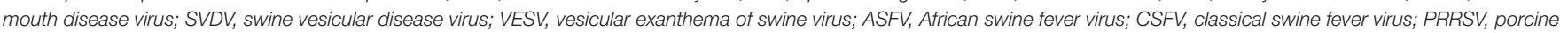

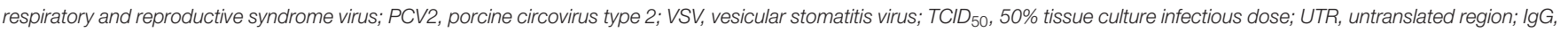
immunoglobulin G; NA, data not available.

exploited for multiplex detection. Reid et al. (15) developed a multiplex RT-qPCR assay using primer/probe sets targeting the FMDV VP1 coding region for detection and differentiation of FMDV serotypes $\mathrm{O}, \mathrm{A}$, and Asia 1 circulating in the
Middle East. Nonetheless, when compared to single RT-qPCR, multiplex RT-qPCR tends to produce false-negative results due to mismatch in the probe-binding regions, suggesting that a higher sequence identicality is required for application in 
multiplex system. This complexity has limited the usage of this technique.

Although highly reliable, RT-qPCR often requires laboratory setting with a qPCR thermocycler, a cost factor that limits its usage in the field. To overcome such limitation, on-site devices capable of performing FMDV diagnosis in the field have been developed, such as the fully automated cartridge-based RT-qPCR diagnostic system, Enigma MiniLab ${ }^{\circledR}$ (18). Another handheld RT-qPCR device, Biomeme two $3^{\mathrm{TM}}$ (two3) has also been developed and evaluated as a field-deployable platform for FMDV diagnosis, in which the sensitivity was shown to be almost comparable to RT-qPCR using the ABI7500 platform (19). The RNA samples can be extracted with an on-site RNA extraction kit such as Biomeme M1 Sample Prep ${ }^{\mathrm{TM}}$ cartridge kit, a method that is dispensable of laboratory equipment and chemicals such as microcentrifuge, alcohol, phenol, and chloroform (19).

Another modified version of RT-PCR known as the RTinsulated isothermal PCR (RT-iiPCR) assay was also developed for qualitative detection of FMDV (12). Unlike traditional PCR that requires cycles of multiple temperatures, RT-iiPCR utilizes a temperature gradient generated from a thermal convection from a single heating source, which hastens the detection process (12). Additionally, RT-recombinase polymerase amplification (RT-RPA) has also been used for detection of $\operatorname{FMDV}(14,40)$. The RT-RPA uses three specific proteins: recombinase allows primer annealing to double-stranded DNA; single-stranded DNA-binding protein stabilizes primer binding; and stranddisplacing DNA polymerase. As for real-time detection, another method based on water-oil emulsion droplet technology for partition of nanoliter droplets containing viral cDNA, known as the RT-droplet digital PCR (RT-ddPCR) was established for the absolute quantitation of FMDV RNA in epithelial and esophageal-pharyngeal fluid samples from FMDV-infected cattle (13).

Generally, the FMDV RNA for diagnostic purposes could be obtained from specimens, which include (i) swabs of oral, nasal, and lesion; (ii) epithelial tissue suspensions; and (iii) oral or vesicular fluid. In a recent study, Goller et al. (18) explored milk as a non-invasive sample for FMDV surveillance using RTqPCR. They demonstrated that the RT-qPCR on milk sample was capable of detecting FMDV RNA 18 days after contact, which is later than the viral RNA detected in serum samples, suggesting milk as a feasible sample for FMD surveillance $(18,21)$. In addition, EDTA-treated blood samples have also been explored as a source of the viral RNA for the diagnosis of FMDV using RTqPCR, owing to the samples' stability during transportation, as well as the ease of sample processing at the diagnostic laboratory (41). Fontél et al. (41) reported that the diagnostic assay using EDTA-treated blood samples was $\sim 10$ times less sensitive than that of serum samples. However, the study used double the volume of serum than that of EDTA-treated blood samples for RNA extraction, of which the serum contains almost double the virus concentration with the same sample volume as the red blood cells were spun off during centrifugation. This gave rise to an uneven amount of virus/volume in each sample type, with serum containing nearly four times the amount of virus, thereby resulting in a difference in cycle threshold $(\mathrm{Ct})$ value of $\sim 2$, assuming that both types of samples were equally good for RT-qPCR detection. The results obtained by Fontél et al. (41) showed that the $\mathrm{Ct}$ value for serum was three to four times lower than that of EDTA-treated blood, in which the actual difference should be only 1- to 2-fold lower. Therefore, EDTA-treated blood samples, as initially proposed by Fontél et al. (41), may still remain a viable option for FMDV diagnosis.

\section{Reverse Transcription-Loop-Mediated Isothermal Amplification}

Unlike PCR that requires cycles of different temperatures for amplification of DNA, LAMP is a method capable of amplifying DNA at a single temperature at around $60^{\circ}$ to $65^{\circ} \mathrm{C}$. It was first invented by Notomi et al. (42), and the method was demonstrated to be highly sensitive and specific. In general, the method involves the use of at least four primers and a DNA polymerase with high strand displacement activity. Two of the primers form loop structures at their respective $5^{\prime}$ ends, and the other two primers play the role of displacing the loop-forming strands from the template at the loop regions as they are being synthesized by DNA polymerase with high strand displacement activity. Once a double-stranded product with both ends capable of forming loop structures is synthesized, it then functions as a template for infinite amplification of the DNA, provided there are still loop-forming primers and dNTPs available. Loop-mediated isothermal amplification is capable of producing $10^{9}$ copies of DNA in less than an hour (42), which probably exceeds the speed of PCR amplification, as no denaturation of double-stranded DNA is required. Another significant difference between LAMP and PCR is their amplification products. While PCR generates high copy numbers of identical products, LAMP generates a mixture of stem-loop DNAs, which can be observed through visual detection, based on the formation of insoluble magnesium pyrophosphate, which can be detected by simple turbidimeter or visual turbidity (43).

As FMDV is an RNA virus, RT-LAMP is needed for detecting the FMDV genomic sequence. Before the doublestranded DNA template with both loop-forming ends can be generated, a loop-forming primer targeting the positivesense RNA template accompanied by reverse transcriptase is required to generate the RNA-DNA hybrid, which will then be displaced by another primer targeting the RNA template at the loop-forming region of the DNA strand through the displacement activity of the DNA polymerase. The antisense viral DNA will then function as a template for LAMP as described above.

RT-LAMP was first employed for FMDV diagnosis by Dukes et al. (44), targeting the FMDV 3D RNA polymerase gene, and the products of amplification can be visually inspected for turbidity, analyzed using agarose gel electrophoresis, or monitored in real time through addition of fluorescent dyes. Three years later, Li et al. (45) used RT-LAMP for detection of FMDV by targeting a conserved region within the FMDV polyprotein gene (3D), at positions 7,905-8,094 of FMDV O isolate olbfs 46 iso46 (GenBank accession no. AY593816). Thereafter, detections of FMDV serotypes $C$ and Asia 1 using specific primers have 
also been reported $(23,24)$. Generally, for detection of FMDV regardless of serotypes, RT-LAMP requires a longer conserved region for primer design compared to RT-PCR and RT-qPCR, as RT-LAMP requires four to six primers to function. Although the target gene selected for detection is highly conserved, some degree of differences exists between different FMDV isolates (25), which will result in mismatch of nucleotides between primers and the target gene, thereby lowering the assay's sensitivity.

As FMDV genomic sequences vary widely between different serotypes, primers used for the detection of one particular serotype may not detect FMDV of another serotype. Therefore, Yamazaki et al. (25) developed a multiplex RT-LAMP, which contains multiple primer sets targeting the $3 \mathrm{D}$ conserved regions for the detection of FMDV regardless of serotypes, in which the assay's sensitivity and specificity were reported to be up to 98.0 and $98.1 \%$, respectively. In each multiplex reaction tested, a combination of two primer sets was used. Unlike RT-PCR, RTLAMP uses primer sets containing around six oligonucleotides with overlapping sequences. As multiplex RT-LAMP involves mixing of primer sets for simultaneous detection of different target genes, its application could be limited by the number of primer sets that can be used in a single reaction, as increase in varieties of primer sequences may increase the rate of unspecific binding, thereby affecting the assay's specificity. In addition, antigen capture RT-LAMP (Ag-RT/LAMP) assay has also been reported to be capable of detecting and serotyping FMDV. An anti-FMDV immunoglobulin G (IgG) that interacts with the VP1 epitope was immobilized on a tube to capture FMDV of various genotypes, and subsequently the viral 3D conserved region was amplified using RT-LAMP amplification (30). Although this method provides an alternative for the differential detection of FMDV using RT-LAMP, the method is heavily dependent on the efficiency of antibody used to capture the target virus. In addition, this method requires a longer time for completion compared to normal RT-LAMP, as extra incubation time is needed for capturing of target virus by antibody. In addition, the specificity of Ag-RT/LAMP has also been reported to be affected by high viral loads in samples of interest.

In a separate study, RT-LAMP was used together with a lateral flow device (LFD) for the detection of FMDV in minimally processed (without RNA extraction) samples (46). Although the coupling of LFD did not increase the assay's sensitivity, it allowed an easier interpretation of the test results compared to visual detection of turbidity from magnesium pyrophosphate, or color changes of double-stranded DNA-staining dyes. The combined use of RT-LAMP and LFD will be discussed in more detail under the subsection chromatographic strip test. For FMDV detection, RT-LAMP has been demonstrated to have an analytical sensitivity of 10-folds lower than that of the conventional RT-PCR, which is 10 -folds lower than that of RT-qPCR method (26). To increase the sensitivity of RT-LAMP, a recent study that used swarm primers to improve the accessibility of DNA to standard LAMP primers was deployed for rapid and accurate diagnosis of FMDV from the pool-1 region (26). At a high concentration, swarm primers anneal to the double-stranded cDNA at higher rate, thereby exposing the inner primer annealing sites, facilitating the binding of the RT-LAMP primers, which results in a faster amplification rate, as well as more RT-LAMP products. Overall, the swarm primer-based RT-LAMP (sRT-LAMP) has been demonstrated to have analytical sensitivity of 10 -folds higher than the conventional RT-PCR, which is comparable to RT-qPCR for FMDV detection.

To date, real-time RT-LAMP (qRT-LAMP) is available for the detection and differentiation of FMDV serotypes $\mathrm{O}, \mathrm{A}$, and Asia 1 (47). Unlike RT-qPCR, qRT-LAMP for FMDV detection could not produce accurate quantitative results, as measurements of magnesium pyrophosphate by turbidity or DNA by fluorogenic dye are directly proportional to the size of LAMP products. As LAMP products are of many different sizes, these methods could not truly reflect the number of replication cycle as in RT-qPCR. Recently, real-time detection and monitoring of LAMP using self-quenching and dequenching fluorogenic probes for direct quantification of LAMP products have been developed (48). However, this method has yet been applied for the detection of FMDV. RT-LAMP was used for detecting and serotyping FMDV in India and Pakistan, in which the results were reported to be comparable to RT-qPCR (27, 29, 31). Another study in Africa demonstrated that RT-LAMP outperformed RT-qPCR in the detection of FMDV (49), although further testing with a bigger sample size and a wide variety of serotypes is needed to support the finding. However, without the need of sophisticated devices as in RT-qPCR, RT-LAMP represents a potential method to be used for on-site diagnoses of FMDV. To further encourage the use of RT-LAMP in laboratory and field settings, Howson et al. (28) demonstrated the use of lyophilized reagents for RT-LAMP (Enigma Diagnostics Limited) and RT-qPCR (OptiGene Limited), in which lyophilization greatly improved the storage stability of test reagents without jeopardizing the assays' performance.

\section{SEROLOGICAL METHODS}

Serological methods detect the presence of viral antigens or antibodies in serum or other body fluid samples. Apart from detecting the viral genome 1 to 2 days postinfection in oral fluid and serum samples (50, 51), FMD diagnosis can also be confirmed through the detection of anti-FMDV antibodies in serum samples. As infection by FMDV will often result in the production of antibodies against the viral antigens (detectable $\sim 4$ days postinfection in cattle sera) (50), detection of these antibodies can therefore indicate the presence of current or past infection. Some of the serological detection methods include VNT, solid-phase competition (SPC) ELISA, and liquid-phase blocking (LPB) ELISA. When ELISA-based methods are used to detect antibodies against both the structural proteins (SPs) and non-structural proteins (NSPs), it is capable of differentiating the infected from vaccinated animals (DIVA), which will be discussed in detail in Enzyme-Linked Immunosorbent Assay. Table 2 summarizes recent studies on ELISA-based FMDV diagnostic assays.

\section{Enzyme-Linked Immunosorbent Assay}

Enzyme-linked immunosorbent assay, pioneered by Engvall and Perlmann (85), is an analytical method commonly used 
TABLE 2 | Enzyme-linked immunosorbent assay (ELISA)-based methods for FMDV diagnosis.

\begin{tabular}{|c|c|c|c|c|c|}
\hline Methods & Description & $\begin{array}{l}\text { Diagnostic } \\
\text { sensitivity }\end{array}$ & $\begin{array}{l}\text { Diagnostic } \\
\text { specificity }\end{array}$ & $\begin{array}{l}\text { Tested clinical } \\
\text { samples }\end{array}$ & References \\
\hline \multirow[t]{5}{*}{ Indirect ELISA } & $\begin{array}{l}\text { Fusion of FMDV VP1 to capsid protein of bacteriophage T7 that } \\
\text { served as coating antigen reacted with the vaccinated and positive } \\
\text { infected bovine sera. A highly conserved shorter VP1 was later } \\
\text { fused to the capsid protein of T7 and was demonstrated to be a } \\
\text { suitable diagnostic reagent for identification of antibodies directed } \\
\text { against this region }\end{array}$ & $92-100 \%$ & $75-87.5 \%$ & $\begin{array}{l}\text { Serum samples of } \\
\text { bovine origin }\end{array}$ & $(52,53)$ \\
\hline & $\begin{array}{l}\text { An assay that utilizes a multiple-epitope protein (B4) comprising } \\
\text { the G-H loops of VP1 from three topotypes of FMDV serotype } \mathrm{O} \\
\text { as diagnostic antigen. The assay successfully detected serum } \\
\text { antibodies against FMDV serotype } \mathrm{O} \text { in vaccinated pigs }\end{array}$ & $95.9 \%$ & $96.7 \%$ & $\begin{array}{l}\text { Serum samples from } \\
\text { pigs }\end{array}$ & $(54,55)$ \\
\hline & $\begin{array}{l}\text { An assay that utilizes baculovirus-expressed recombinant } 3 A B C \text { of } \\
\text { FMDV as coating antigen for detection of } 3 A B C \text {-specific } \\
\text { antibodies in FMDV-infected animals }\end{array}$ & $95.8 \%$ & $97.45 \%$ & $\begin{array}{l}\text { Serum samples of } \\
\text { bovine origin }\end{array}$ & (56) \\
\hline & $\begin{array}{l}\text { A negative marker virus was produced by deleting amino acid } \\
\text { residues } 93-143 \text { of the } 3 A \text { and } 10-37 \text { of } 3 B \text { of FMDV. ELISA } \\
\text { developed to target the deleted region was reported to allow DIVA }\end{array}$ & $95.5 \%$ & $96 \%$ & $\begin{array}{l}\text { Serum samples from } \\
\text { cattle and buffaloes }\end{array}$ & $(57)$ \\
\hline & $\begin{array}{l}\text { A negative marker virus was produced by deleting amino acid } \\
\text { residues } 87-144 \text { in } 3 \mathrm{~A} \text {, and the whole } 3 \mathrm{~B}_{1} \text { and } 3 \mathrm{~B}_{2} \text { of } \mathrm{FMDV} \text {. } \\
\text { ELISA developed to target the deleted region was reported to } \\
\text { allow DIVA }\end{array}$ & $96 \%$ & $97.1-100 \%$ & $\begin{array}{l}\text { Serum samples of } \\
\text { bovine origin }\end{array}$ & (58) \\
\hline \multirow[t]{10}{*}{ Sandwich ELISA } & $\begin{array}{l}\text { Monoclonal and polyclonal antibodies against conserved } \\
\text { structural protein fragment } 1 \mathrm{AB}^{\prime} \text { of FMDV were used as capture } \\
\text { and detection antibodies, respectively, for serotype-independent } \\
\text { detection of FMDV }\end{array}$ & NA & NA & NA & (59) \\
\hline & $\begin{array}{l}\text { Monoclonal antibodies and chicken IgY against } 146 \text { S antigen of } \\
\text { FMDV were used as capture and detection antibodies, } \\
\text { respectively, for detection of FMDV of serotypes O, Asia 1, and A }\end{array}$ & $98.87 \%$ & $100 \%$ & $\begin{array}{l}\text { Tongue epithelial } \\
\text { samples and tissue } \\
\text { culture fluids }\end{array}$ & $(60)$ \\
\hline & $\begin{array}{l}\text { An assay that utilizes baculovirus-expressed recombinant } \\
\text { structural proteins of FMDV as diagnostic antigen for specific } \\
\text { detection of antibodies against FMDV serotype Asia } 1\end{array}$ & NA & $99.7 \%$ & $\begin{array}{l}\text { Serum samples from } \\
\text { cattle, pigs, and goats }\end{array}$ & $(61)$ \\
\hline & $\begin{array}{l}\text { A monoclonal antibody was used as detection antibody for } \\
\text { serotyping of FMDV serotype } O\end{array}$ & $100 \%$ & $100 \%$ & NA & (62) \\
\hline & $\begin{array}{l}\text { A recombinant antibody fragment, single-chain variable fragment } \\
\text { (scFv) was used as detection antibody for the detection of } \\
\text { FMDV-specific IgA in salivary samples }\end{array}$ & NA & NA & $\begin{array}{l}\text { Saliva samples from } \\
\text { cattle, buffaloes, sheep, } \\
\text { goats, and canines }\end{array}$ & (63) \\
\hline & $\begin{array}{l}\text { A recombinant integrin } \alpha v \beta 6 \text { and serotype-specific monoclonal } \\
\text { antibodies were used as antigen-trapping and detection reagents, } \\
\text { respectively, for identification and serotyping of FMDV }\end{array}$ & $97.9 \%$ & $96 \%$ & $\begin{array}{l}\text { Positive cell-culture } \\
\text { supernatants }\end{array}$ & $(64,65)$ \\
\hline & $\begin{array}{l}\text { A truncated bovine integrin } \alpha \vee \beta 6 \text { was used as a universal trapping } \\
\text { reagent in a sandwich ELISA for all FMDV serotypes. When } \\
\text { coupled to serotype-specific monoclonal antibodies, the integrin } \\
\text { can be employed to detect viruses representing all seven FMDV } \\
\text { serotypes }\end{array}$ & NA & NA & Infected cell lysate & (66) \\
\hline & $\begin{array}{l}\text { A recombinant, bacteria-expressed, conserved region of } 3 \text { ABC } \\
\text { and a monoclonal antibody were used as diagnostic antigen and } \\
\text { capture antibody in the assay for differentiation of infected animals } \\
\text { from vaccinated animals }\end{array}$ & $98.4 \%$ & $100 \%$ & $\begin{array}{l}\text { Serum samples of } \\
\text { swine origin }\end{array}$ & (67) \\
\hline & $\begin{array}{l}\text { An assay that utilizes the bacteria-expressed truncated } 3 \text { ABC of } \\
\text { FMDV SAT } 2 \text { serotype as diagnostic antigen for detection and } \\
\text { differentiation of FMDV SAT serotype-infected animals from } \\
\text { vaccinated animals }\end{array}$ & $76 \%$ & $96 \%$ & $\begin{array}{l}\text { Serum samples of } \\
\text { bovine origin }\end{array}$ & (68) \\
\hline & $\begin{array}{l}\text { A negative marker virus with partial deletion in the VP1 G-H loop } \\
\text { was generated. ELISA targeting deleted region was suggested to } \\
\text { allow differentiation of infected from vaccinated animals }\end{array}$ & NA & NA & $\begin{array}{l}\text { Serum samples of } \\
\text { bovine origin }\end{array}$ & $(69,70)$ \\
\hline
\end{tabular}


TABLE 2 | Continued

\begin{tabular}{|c|c|c|c|c|c|}
\hline Methods & Description & $\begin{array}{l}\text { Diagnostic } \\
\text { sensitivity }\end{array}$ & $\begin{array}{l}\text { Diagnostic } \\
\text { specificity }\end{array}$ & $\begin{array}{l}\text { Tested clinical } \\
\text { samples }\end{array}$ & References \\
\hline \multirow[t]{5}{*}{ LPB-ELISA } & $\begin{array}{l}\text { An assay utilizes two neutralizing monoclonal antibodies specific } \\
\text { against FMDV serotype } O \text { as trapping and detection antibodies. } \\
\text { Results generated from the assay correlated well with the results } \\
\text { of VNT }\end{array}$ & NA & $99.7-100 \%$ & $\begin{array}{l}\text { Serum samples of } \\
\text { bovine and porcine } \\
\text { origins }\end{array}$ & (71) \\
\hline & $\begin{array}{l}\text { An assay for detecting antibodies against FMDV based on single } \\
\text { dilution of the serum. Antibody titers against FMDV of serotypes } \\
\mathrm{O}, \mathrm{A}, \mathrm{C} \text {, and Asia } 1 \text { could be extrapolated from a linear regression } \\
\text { curve generated with reference standards }\end{array}$ & NA & NA & $\begin{array}{l}\text { Serum samples from } \\
\text { cattle }\end{array}$ & $(72,73)$ \\
\hline & $\begin{array}{l}\text { An assay utilizes baculovirus-expressed recombinant structural } \\
\text { proteins of FMDV as diagnostic antigen for specific detection of } \\
\text { antibodies against FMDV serotype A }\end{array}$ & NA & $98.5-99 \%$ & $\begin{array}{l}\text { Serum samples from } \\
\text { cattle, pigs, and goats }\end{array}$ & $(74)$ \\
\hline & $\begin{array}{l}\text { Field application of an assay utilizing recombinant structural } \\
\text { proteins of FMDV as diagnostic antigen for specific detection of } \\
\text { antibodies against FMDV serotype A }\end{array}$ & $84 \%$ & $97 \%$ & $\begin{array}{l}\text { Serum from beef, dairy, } \\
\text { and deer farms }\end{array}$ & (75) \\
\hline & $\begin{array}{l}\text { VHHs specific to } 146 \text { S antigen of FMDV serotypes O, A, and Asia } \\
1 \text { were used as trapping antibodies in LPB-ELISA. The assay } \\
\text { produced results that correlate well to routine LPB-ELISA, which } \\
\text { uses coating antibodies from rabbits }\end{array}$ & NA & NA & $\begin{array}{l}\text { Serum samples of } \\
\text { bovine origin }\end{array}$ & (76) \\
\hline \multirow[t]{6}{*}{ SPC-ELISA } & $\begin{array}{l}\text { An assay for detecting antibodies against FMDV antigen (146S). } \\
\text { The assay was demonstrated to successfully detect antibodies } \\
\text { against FMDV of A, C, SAT 1, SAT 2, SAT 3, and Asia } 1 \text { serotypes } \\
\text { in infected samples }\end{array}$ & NA & $99.41-99.9 \%$ & $\begin{array}{l}\text { Serum samples from } \\
\text { cattle, sheep, and pigs }\end{array}$ & $(77)$ \\
\hline & $\begin{array}{l}\text { A commercially available kit based on SPCE-ELISA for detection } \\
\text { of antibody against FMDV serotype O was reported to produce } \\
\text { high false-positive rate }\end{array}$ & NA & NA & $\begin{array}{l}\text { Serum samples from } \\
\text { pigs }\end{array}$ & (78) \\
\hline & $\begin{array}{l}\text { An assay that utilizes bacterial-expressed recombinant capsid } \\
\text { polyprotein as diagnostic antigen for specific detection of } \\
\text { antibodies against FMDV serotype } \bigcirc\end{array}$ & $99 \%$ & $100 \%$ & $\begin{array}{l}\text { Serums samples from } \\
\text { cattle, buffaloes, and } \\
\text { goats }\end{array}$ & (79) \\
\hline & $\begin{array}{l}\text { An assay that utilizes bacterial-expressed virus-like particles of } \\
\text { FMDV as diagnostic antigen for detection of antibodies against } \\
\text { FMDV serotype O. The assay produced results comparable to } \\
\text { commercially available kits }\end{array}$ & $96 \%$ & $100 \%$ & $\begin{array}{l}\text { Serum samples of } \\
\text { bovine, pig, and sheep } \\
\text { origins }\end{array}$ & (80) \\
\hline & $\begin{array}{l}\text { Two serotype-specific monoclonal antibodies targeting the } \\
\text { conserved VP2 regions of FMDV serotype A were used as } \\
\text { competing antibodies in SPC-ELISA. The test detected antibodies } \\
\text { directed against FMDV serotype A, and the results were } \\
\text { comparable to VNT }\end{array}$ & $99.3 \%$ & $99.7 \%$ & $\begin{array}{l}\text { Serum samples of } \\
\text { bovine, porcine, and } \\
\text { ovine origins }\end{array}$ & (81) \\
\hline & $\begin{array}{l}\text { The bacterial-expressed, recombinant } 3 \mathrm{ABC} \text { of FMDV and VHHs } \\
\text { were used as diagnostic antigen and competing antibodies in } \\
\text { SPC-ELISA for detection and differentiation of FMDV-infected } \\
\text { animals from vaccinated animals }\end{array}$ & $94 \%$ & $97.67 \%$ & $\begin{array}{l}\text { Serum samples from } \\
\text { cattle }\end{array}$ & (82) \\
\hline $\begin{array}{l}\text { Microchip-based } \\
\text { ELISA }\end{array}$ & $\begin{array}{l}\text { An assay that involves immobilization of the recombinant } 3 A B C \\
\text { polyprotein to microbeads followed by immunoreaction with the } \\
3 A B C \text {-specific antibodies in the test sera, and detection with } \\
\text { thermal lens microscopy-based on the enzymatically colorimetric } \\
\text { reaction between HRP-labeled antibody and the corresponding } \\
\text { substrate }\end{array}$ & NA & NA & $\begin{array}{l}\text { Serum samples from } \\
\text { cattle and swine }\end{array}$ & $(83,84)$ \\
\hline
\end{tabular}

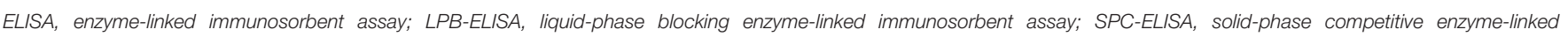

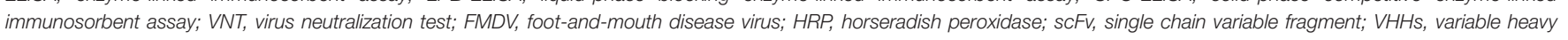
chain antibody fragments; IgY, immunoglobulin Y; NA, data not available.

for qualitative and quantitative analyses. Current ELISA is a modified version of radioimmunoassay techniques, which was first described by Coons et al. (86), in which an antigen is immobilized on a solid phase either directly or indirectly to capture a targeted antibody, which is then reported through a secondary antibody conjugated to an enzyme, where signals will 
be generated in the presence of its corresponding substrate. In general, ELISA is categorized into direct, indirect, sandwich, and competitive ELISA (87). Currently, ELISA is one of the most common approaches in detection of FMDV in addition to the virus isolation, VNT, and PCR-based techniques (88). According to a report from the Regional Reference Laboratory for FMD in South East Asia, more than 13,000 ELISAs were performed compared to 304 VNTs and 790 PCR-based assays for diagnosis of FMD in 2017 (89).

Detection of FMDV specific antibodies in vaccinated bovine sera using an indirect ELISA was first reported by Abu Elzein and Crowther (90), in which the test sera from cattle reacted with the FMDV coated on the microtiter plate followed by detection with anti-bovine antiserum conjugated to an enzyme. Subsequently, the same research group demonstrated the capability of a sandwich ELISA in detecting and quantifying FMDV with 50 to 100 times higher sensitivity than CFT (91). A doublesandwich ELISA method developed by Roeder and Le Blanc Smith (92) further improved the sensitivity of FMDV detection with 125 times higher than that of CFT. Unlike CFT, specific detection of FMDV using the sandwich ELISA was reported to be unaffected by the presence of $12 \mathrm{~S}$ antigen (93) and procomplementary or anticomplementary factors in the samples (88). Moreover, the sandwich ELISA allows direct assessment of samples without virus isolation, and it is generally more cost-effective than CFT because of the lower amount of sera required per test (88). In addition, ELISA is not affected by the variation in tissue culture susceptibility (88). Comparative studies via repeated testing of sera also indicated that ELISA was more reproducible than VNT, and their results could be generated within a day compared to VNT, which normally took more than 3 days (94).

Measurements of antibody titers using ELISA involve passive absorption of an antigen to a solid phase support, particularly the microtiter plate wells. Several studies have indicated that passive absorption of an antigen to a solid support either directly or indirectly via trapping antibodies may distort the conformation of the antigen. The conformation of FMDV antigen was previously reported to be altered with the exposure of internal viral proteins following a non-covalent binding to a PVC plate in an indirect ELISA (95-97). To resolve this problem, an LPB-ELISA was developed for the determination of antibody reactivity to the $146 \mathrm{~S}$ antigen in its most native conformation (97). In this assay, the $146 \mathrm{~S}$ antigen and test sera were mixed and incubated before being transferred to a plate precoated with serotype-specific anti-FMDV antisera (94). Attributed to the good reproducibility, faster results, and good correlation with VNT, LPB-ELISA quickly replaced VNT in FMD routine screening (98). Liquid-phase blocking ELISA was also reported to be the best strategy in differentiating the antigenic differences between FMDV strains (99). Nevertheless, the LPB-ELISA was shown to produce some degree of false-positive results and may require VNT for additional verification in some of the lowpositive LPB-ELISA results (98). Conventionally, to measure the antibody titer by endpoint titration using LPB-ELISA requires the serum to be serially diluted, which is more laborious and more prone to error. To overcome this problem, a single-dilution
LPB-ELISA was previously developed to measure the FMDV-specific antibody titer in serum. This method is based on a linear regression curve generated with reference standards to extrapolate the antibody titers of the sera tested $(72,73)$.

An SPC-ELISA was also developed for detecting FMDV (98). This method is based on the competition between the antibodies in the sera tested and the serotype-specific guinea pig anti-FMDV antibodies (98). Although both the LPB-ELISA and SPC-ELISA were shown to have similar sensitivity and limit of detection, the specificity of SPC-ELISA was reported to be higher, offering an improved FMDV-specific antibody detection method for mass screening (98). Paiba et al. (100) also demonstrated that SPC-ELISA was more sensitive than VNT for early serological detection of FMDV infection in cattle and sheep, although opposite findings were observed when tested in pigs. In addition, the sensitivity of SPC-ELISA is less affected by the strains of FMDV used in the assay, whereas VNT sensitivity could reduce significantly if heterologous virus is employed (100). Solid-phase competition ELISA was reported to be able to detect antibodies against six non-O serotypes of FMDV (A, C, SAT 1, SAT 2, SAT 3, and Asia 1) with specificity ranging from 99.4 to $99.9 \%$ and sensitivity comparable to LPB-ELISA and VNT (77). On the other hand, serotype specificity of the SPC-ELISA was evaluated against different reference sera representing six FMDV serotypes (O, A, Asia 1, SAT 1, SAT 2, and SAT 3). The SPC-ELISA detected all the reference sera correctly but not the FMDV serotype SAT 3-positive serum. Similarly, VNT also produced a borderline positive response on this sample, suggesting that the sample might be degraded. In addition, cross-reaction in SPC-ELISA between FMDV serotypes A and Asia 1-positive samples was observed (77). Solid-phase competition ELISA kits for detection of specific SPs of FMDV of different serotypes were commercially available. Nevertheless, one recent study reported that the sensitivity of the SPC-ELISA kit for specific detection of FMDV serotype $\mathrm{O}$ was lower, and it produced more false-positive results as compared to LPB-ELISA and VNT (78).

To improve the performance of ELISA in FMD diagnosis, many modifications have been made, primarily focusing on the development of new coating antigens and new monoclonal antibodies (mAbs) as trapping or detection antibodies. Majority of the ELISA-based assays involve inactivated FDMV antigens in the diagnostic process. However, the production of these inactivated antigens still requires handling of live virus in highcontainment laboratories (101). Along with the advancement in recombinant DNA technology, coating antigens can be produced in a safer alternative. Recombinant SPs of FMDV serotypes $\mathrm{O}$, Asia 1, and A were generated via the baculoviral expression system and used as diagnostic antigens in LPBELISA $(61,74)$. These recombinant LPB-ELISA assays exhibited specificity and sensitivity comparable to VNT (74). When this method was applied in the field during an FMDV serotype A outbreak in Korea in 2010, its specificity and sensitivity were reported to be 97 and 84\%, respectively (75). The SPs VP1, VP2, VP3, and VP4 are the secondary cleavage products of a capsid precursor polyprotein (P1) of FMDV (102). Biswal et al. (79) produced a recombinant capsid polyprotein ( $\mathrm{rP1}$ ) and 
employed it as a diagnostic antigen in SPC-ELISA for detection of FMDV serotype O. Solid-phase competition ELISA based on rP1 demonstrated $100 \%$ specificity and $99 \%$ sensitivity. In addition, virus-like particles of FMDV serotype $\mathrm{O}(80)$ were also produced and used as a diagnostic antigen in SPC-ELISA. The specificity and sensitivity of this test were 100 and $96 \%$, respectively (80). Interestingly, Wong et al. (52) genetically fused the capsid protein of T7 bacteriophage with the VP1 of FMDV and demonstrated that the recombinant protein, when served as the coating antigen in an indirect ELISA, could react with the vaccinated and positive infected bovine sera, suggesting its potential application in FMD diagnosis. Wong et al. (53) further delineated the VP1 sequence of FMDV to 12-amino-acid residues using amino acid sequence alignment, homology modeling, and phage display, in which the chimeric phage T7 displaying VP1 $159-170$ epitope was demonstrated to have an improved sensitivity of $100 \%$ in a phage-based ELISA. Recently, a multiple-epitope protein (B4) comprising the G-H loops of VP1 from three topotypes of FMDV serotype $\mathrm{O}$ was developed as a potential vaccine candidate (54, 103). When the B4 was employed as a coating antigen in an indirect ELISA, it detected antibodies against FMDV serotype $\mathrm{O}$ in pigs with specificity and sensitivity up to 96.7 and $95.9 \%$, respectively. These results were also reported to correlate well with the LPB-ELISA (55).

Serotyping and identification of FDMV based on sandwich ELISA normally use rabbit and guinea pig polyclonal antibodies as capture and detection antibodies, respectively. However, there are some disadvantages of using these polyclonal antibodies in ELISA, including batch-to-batch variation, inconsistent yield of antibodies, and limited serum samples collectable from individual animals (60). van Maanen (104) demonstrated the use of mAbs in ELISA for identification of three FMDV serotypes (A10, O1, C1). This mAb-based ELISA (mAb-ELISA) was shown to be sensitive, specific, and more reproducible than VNT. In the same year, Smitsaart et al. (105) developed a competition ELISA using an $\mathrm{mAb}$ that binds to the $12 \mathrm{~S}$ protein subunit. This assay successfully detected six of the seven serotypes of FMDV with a sensitivity higher than that of CFT (105). More mAbs were later developed and utilized as trapping and/or detection antibodies in ELISA for FMDV detection (59, 62, 106-109). Veerasami et al. (60) also produced mAbs and chicken IgY specifically against the $146 \mathrm{~S}$ antigen of three FMDV serotypes $(\mathrm{O}$, Asia 1, and A) and used them in ELISA as capture and detection antibodies, respectively. There are several advantages in using chicken IgY in ELISA for FMD detection including minimal or no cross-reaction with mammalian IgG, complete absence of non-specific binding, and elimination of the need for crossspecies immunoabsorptions due to the phylogenetic differences between birds and mammals (60). This method produced results comparable to the routine ELISA and RT-qPCR in FMDV serotyping (60). Another two mAbs that bind specifically to VP2 protein of FMDV serotype A were generated and employed as competing antibodies in SPC-ELISA. These mAbs interact with the VP2 protein, which is more conserved, thus offering a distinct advantage over another similar assay, which targets the more variable VP1 protein of FMDV serotype A $(74,81)$. This assay demonstrated specificity and sensitivity of 99.7 and
99.3\%, respectively (81). In addition, two neutralizing mAbs, namely $72 \mathrm{C} 1$ and $65 \mathrm{H} 6$, which were raised against the FMDV O/JPN/2000 strain, were previously employed in LPB-ELISA as trapping and detection antibodies, respectively. This modified LPB-ELISA produced results that correlated well with VNT and demonstrated specificity of 100 and $99.7 \%$ in negative bovine and swine sera, respectively (71).

Apart from mAbs, recombinant antibody fragments such as the single-chain variable fragments (scFvs) were also used as detection antibodies in sandwich ELISA to detect FMDV-specific IgA in salivary samples from vaccinated and infected cattle (63). In addition, the variable heavy chain antibody fragments (VHHs) from camels have been explored for FMD diagnostic applications (76). The VHHs are composed of two heavy chains, but lack the light chains and $\mathrm{CH} 1$ domain present in conventional antibodies (110). Dash et al. (76) produced VHHs that bind specifically to 146S antigen of FMDV serotypes O, A, and Asia 1 and used them as trapping antibodies in LPB-ELISA. This modified LPBELISA yielded results that correlate well to routine LPB-ELISA, which uses coating antibodies from rabbits (76). The FMDVspecific VHHs could be produced with bacterial expression system, offering batch uniformity, and thus lower the production cost (111).

All field isolates of FMDV initiate infection using arginineglycine-aspartic acid-binding integrins as the cell receptors (66). This knowledge was leveraged for the development of FMD diagnostic tools. A recombinant integrin $\alpha \mathrm{v} \beta 6$ was previously produced as an antigen-trapping reagent in a sandwich ELISA for FMDV diagnosis (64). When the serotype-specific polyclonal and mAbs were used as the detection antibody, the sensitivity of these methods was reported to be 98.1 and $97.9 \%$, respectively. Nevertheless, the latter demonstrated superior serotypic specificity (96\%) to that of the former (61.5\%) (65). Later, Shimmon et al. (66) also generated a truncated bovine integrin $\alpha v \beta 6$ as a universal trapping reagent in a sandwich ELISA for FMDV detection. Serotype specificity of sandwich ELISA assays based on the integrin $\alpha v \beta 6$ ( $\alpha v \beta 6$-ELISA) was evaluated against FMDV-positive sera representing all seven serotypes. Depending on the serotype specificity of the $\mathrm{mAb}$ used for detection, little to no cross-reactivity was observed. Additionally, different sensitivities were observed when the $\alpha v \beta 6$ ELISA was tested against different FMDV strains within the same serotypes $(65,66)$.

\section{Differentiation/Discrimination of Infected From Vaccinated Animals}

Exposure of animals to inactivated or live FMDV during vaccination or infection induces antibodies specific to the SPs. Therefore, a detection method targeting the SPs of FMDV alone cannot differentiate between the infected and vaccinated animals. Although the SPs and NSPs of FMDV are immunogenic, only the SPs serve as the main immunogen for the induction of protective responses $(112,113)$. Thus, the elimination of the NSPs from the inactivated FMDV vaccine could enable DIVA via differential detection of NSP-specific antibodies in animals infected with FMDV $(114,115)$. With some modifications, conventional ELISA 
methods have been adopted for the detection of NSPs of FMDV. Different NSPs of FMDV including 3ABC, 3AB, 3A, 3B, 3D, 2C, and $2 \mathrm{~B}$ proteins have been employed in the establishment of NSP-based ELISAs.

Among the NSPs of FMDV, 3ABC polyprotein is reported to be the most antigenic and the most reliable marker for DIVA. Various formats of ELISA based on the $3 \mathrm{ABC}$ polyprotein were developed, including the LPB-ELISA, SPC-ELISA, and direct/indirect sandwich ELISA, all of which demonstrated good sensitivity, specificity, and capability for DIVA in various animals (56, 67, 68, 116-125). Enzyme-linked immunosorbent assays based on $3 \mathrm{ABC}$ have some added advantages over other NSPs including superior longevity of anti-3ABC antibody in infected animals compared to $2 \mathrm{C}, 3 \mathrm{~A}, 3 \mathrm{D}$, and $\mathrm{Lb}$, and all infected cattle were shown to develop $3 \mathrm{ABC}$-specific antibody at some points following the infection. Seroconversion to $3 \mathrm{ABC}$ in infected cattle was observed at 11 days postinfection, and the antibody remains detectable to the end of the experiments (301 days postinfection). Furthermore, repeated vaccination (fewer than five vaccinations) of the cattle with FMDV vaccine did not induce any antibody response against $3 \mathrm{ABC}$ polyprotein, in contrary to $3 \mathrm{D}$ protein (126). An agar gel immunodiffusion test was previously developed to detect 3D-specific antibodies in the sera of cattle, sheep, goats, and pigs for DIVA (127), but was found to have low sensitivity and specificity and was later replaced with LPB-ELISA (128). The conventional ELISA based on NSPs of FMDV uses partially purified antigens from infected cell cultures as diagnostic antigens, which require handling of live virus, posing risk of accidental virus escape from laboratories, and these partially purified antigens often lack batch-to-batch uniformity (129). Enzyme-linked immunosorbent assay based on the NSPs produced from either bacterial or baculoviral expression systems overcomes these concerns without compromising the sensitivity and specificity of the test $(126,130)$. Virus-like particles such as the tymovirus-like particles were also engineered to display $3 \mathrm{~B} 1,3 \mathrm{~B} 2,3 \mathrm{AB}, 3 \mathrm{D}$, and $3 \mathrm{ABD}$ of FMDV and used as coating antigens in an indirect ELISA for DIVA (131). Variable heavy chain antibody fragments were also employed as competing antibodies for NSPs in SPC-ELISA and demonstrated high diagnostic specificity and sensitivity in detecting NSP-specific antibodies (82).

To further simplify and speed up the ELISA process for detecting FMDV-infected animals, the microchip-based ELISA was developed. This assay involved immobilization of the $6 \mathrm{x}-$ His tagged recombinant $3 \mathrm{ABC}$ polyprotein to microbeads with nickel (II) chelating chemistry, followed by immunoreaction with the $3 \mathrm{ABC}$-specific antibodies in the test sera and detection with thermal lens microscopy based on the enzymatically colorimetric reaction between HRP-labeled antibody and the corresponding substrate. This method was demonstrated to be capable of detecting anti-3ABC antibodies in infected swine and cattle sera with good sensitivity and reproducibility. This assay is much faster (within $25 \mathrm{~min}$ ) and requires lower serum volume $(83,84)$. Apart from the microchip-based ELISA, a chemiluminescence immunoassay (CLIA) was also developed for rapid identification of the anti-NSP antibodies. Chemiluminescence immunoassay was reported to simultaneously detect antibodies against $3 \mathrm{ABC}$ and 2C proteins of FMDV in experimentally infected pigs with sensitivity and specificity comparable to the commercial kits. This method produced results within $15 \mathrm{~min}$, a remarkably short analysis time compared to other standard ELISA methods (132). Chemiluminescence immunoassay was later applied in the field for DIVA in bovines by simultaneously detecting 3Aand $3 \mathrm{~B}$-specific antibodies in the serum samples. In this field test, CLIA was reported to have concordance rate of $88.1 \%$ with the commercial PrioCHECK ${ }^{\circledR}$ FMDV NSP ELISA kit and produced no false-positive result in sera collected from bovine that had been vaccinated less than five times and low false-positive results in sera collected from bovine that had been vaccinated up to $10(<2.2 \%)$ and 15 times $(<6 \%)$ (133). Chemiluminescence immunoassay that enables simultaneous detection of two different antibodies against different NSPs of FMDV is advantageous over ELISA method, which detects only a single anti-NSP antibody. To ensure accurate diagnosis, retesting positive samples by detecting other antibodies against NSPs is a preferred measure (134).

Foot-and-mouth disease virus vaccines based on inactivated virus may contain a trace amount of FMDV NSPs, which could lead to the production of antibodies against the NSPs upon multiple vaccinations, which affect DIVA diagnosis (114, 130, 135). Negative marker vaccines that protect animals from FMDV infection while allowing DIVA were developed via removal of NSPs, which were used as markers for DIVA (57, 58, 136, 137). Alternatively, non-replicating FMDV virus-like particle was explored by Grubman (138) as a marker vaccine. While most negative marker vaccine developments involve deletion of NSPs, a few studies deleted part of the SPs, particularly the VP1 G-H loop, as the antibodies against G-H loop were demonstrated to be inefficient to provide a good protection $(69,70,139,140)$.

\section{CHROMATOGRAPHIC STRIP TESTS}

Fast detection and accurate identification of FMDV allow effective FMD surveillance and responses by imposing suitable controls and prevention strategies in case of an FMD outbreak. To date, typical assays for FMDV diagnosis such as virus isolation combined with antigen ELISA and RT-qPCR have been employed in FMDV reference laboratories (141). Despite the reliable and accurate diagnoses of FMDV, these diagnostic assays rely heavily on the availability of high-throughput equipment and highly trained personnel. Furthermore, the poor quality of the samples that resulted from the transport of materials from a field to a laboratory may obstruct or delay the early diagnosis of the disease. Thus, alternatives such as isothermal assays and dipsticks assays (also known as chromatographic strip tests) could serve as promising diagnostic methods in the field for a prompt FMD detection to allow timely implemented control measures. Reverse transcription-RPA $(14,40)$, RT-LAMP $(23,25,29,46,47)$, and nucleic-acid sequence-based amplification (142) have been used to detect FMDV. A combination of dipsticks assays with RTLAMP and RT-RPA has also been used for virus serotyping in field samples $(14,28,46)$. Nevertheless, a drawback of the LAMP assay is that it involves the use of a few sets of intricate 
primers, while the RPA products require an electrophoresis setup and a fluorescent probe. Hence, a portable, rapid, and accurate detection method is still prominent for initial diagnosis of FMDV.

A chromatographic strip test such as LFI is a wellestablished fast paper-based analytical platform for detection and quantification of analytes. It is a simple and inexpensive point-of-care (POC) diagnosis without the need of elaborating sample preparations and sophisticated instruments (143). This has led to the increased applications of LFI assay in multiple field conditions where rapid screening is required. Table 3 summarizes LFI assays for FMDV diagnosis. A typical LFI strip normally consists of overlapping membranes that are mounted on a backing card. A liquid sample containing the analyte of interest moves through the cellulose membrane by a capillary force and is captured by the attached molecules that interact with the analyte along the membrane. In this context, a colored or fluorescent particle conjugated with an antibody that interacts specifically with the target analyte is used as the tracer for the development of signal (157). This LFI assay has been widely used for the diagnosis of infectious diseases (158-161) and detection of bioactive molecules $(162,163)$. Without the need of specific instruments, LFI strip test is a low-cost diagnostic method, which is easy to perform, giving straightforward results in a very short time. Lateral flow immunochromatographic strip tests have been used intensively for the detection of serotype-specific FMDV such as type-O $(144,149)$, -A $(144,145)$, -Asia $1(144,150,164)$, and -SAT 2 (147). Likewise, LFI strips used for the detection of non-serotype-specific FMDV have also been reported (147, $151,165,166)$. However, one of the drawbacks for this nonserotype-specific LFI assay is the restricted usage of these strips in endemic countries, where rapid identification is essential for disease control $(167,168)$.

Most of the LFI strips detect FMDV SPs, but detection of specific antibodies against FMDV SPs (149) and NSPs $(148,152)$ has also been performed. Unlike strips that detect SPs, detections of antibodies against SPs are often performed to identify the vaccination status of animals, whereas detections of antibodies against NSPs are used to identify animals that have been infected by FMDV. Yang et al. (149) developed a lateral flow test strip using the recombinant VP1 protein for specific detection of antibodies against FMDV serotype O. Similar to ELISA, LFI test strips that are able to detect antibodies against SPs are unable to differentiate whether an animal that tested positive is vaccinated or infected. Therefore, test strips that detect antibodies against NSPs are required for the purpose of DIVA. Chen et al. (148) used recombinant $3 \mathrm{ABC}$ protein of FMDV serotype $\mathrm{O}$ for the detection of anti-NSPs antibodies in porcine. Although the NSPs of FMDV are highly conserved among all FMDV serotypes, only the samples of serotype $\mathrm{O}$ were tested. Later on, Wu et al. (152) developed an LFI test strip based on the recombinant $2 \mathrm{C}^{\prime} 3 \mathrm{AB}$ protein of FMDV serotype $\mathrm{O}$, in which $3 \mathrm{C}$ was removed because of its low immunogenicity and replaced by part of $2 \mathrm{C}$ protein, which was fused to the $\mathrm{N}$-terminus of $3 \mathrm{AB}$. Despite the high sensitivity and specificity of the test, the serotypes of positive and vaccinated serum samples tested were not reported. The LFI strip technology has also been proposed for use in DIVA, but its practical usage in DIVA has yet been reported.
While most of the LFI strips utilize rabbit and guinea pig polyclonal sera, respectively, as the capture and detection antibodies, the usage of $\mathrm{mAb}$ as the capture and detection antibodies for FMDV detection in the LFI strip tests has also been developed to improve the efficiency of diagnosis (146, $165,166,169)$. For this purpose, strips are specifically designed for each antigen in order to increase the accuracy, sensitivity, and consistency of the assay. Reid et al. (165) reported that an equivalent sensitivity (100\%) to the conventional antigen ELISA was observed in both the clinical samples from animals infected experimentally and in cell culture supernatant using the Clearview $^{\mathrm{TM}}$ chromatographic strip test technology with $\mathrm{mAb}$ isotype IgG1, designated as Cla. The mAb Cla displayed high reactivity against FMDV serotypes $\mathrm{O}, \mathrm{A}, \mathrm{C}$, and Asia 1 and no cross-reactivity with SVDV. Utilization of the mAb approach, in which specific mAbs were used as the capture antibody, and serotype-independent mAbs were employed as the detection antibody, produced a new generation of the generic Rapid Assay Device (gRAD) for the detection of FMDV serotypes $\mathrm{O}, \mathrm{A}$, and Asia 1 (153). The gRAD, which is currently commercially available, has been shown to achieve a sensitivity similar to that of the double antibody sandwich ELISA for viral antigen detection with a detection limit of 2.55 to $6.3 \log _{10} \mathrm{TCID}_{50} / \mathrm{mL}$ of $10 \%$ tissue suspension from epithelial lesions in a process that took only $10 \mathrm{~min}$ (153). Another commercially available LFI strip known as the Svanodip FMDV-Ag LFD by Boehringer Ingelheim Svanova (Sweden) can also be used to detect all the seven serotypes of FMDV antigens based on IF10 mAbs.

As serotype-specific LFI strips can only detect one FMDV serotype at a time (170), thus development of a multiplex platform for simultaneous detection of multiple FMDV serotypes will undoubtedly enhance the usage of the LFI strips in the field. A multiplex-LFI strip test for detecting Hantavirus in humans was developed by Amada et al. (171). The first study describing the development of a multiplex-LFI strip test for detecting FMDV serotypes O, A, and Asia 1 was reported by Yang et al. (151). Following this report, Morioka et al. (154) successfully developed another multiplex FMDV LFI strip based on mAbs that can detect all the seven serotypes and concurrently distinguish serotypes $\mathrm{O}, \mathrm{A}, \mathrm{C}$, and Asia 1. The developed multiplex-LFI strip had a sensitivity ranging from $10^{3}$ to $10^{4}$ of a $50 \%$ tissue culture infectious dose $\left(\mathrm{TCID}_{50}\right)$ of each FMDV strain, comparable to the commercial product, Svanodip FMDV-Ag LFD, which can detect all the seven serotypes of FMDV, but is not able to serotype them.

Recently, a combination of LFI assay and other technologies, such as PCR (172), RT-LAMP (173), RT-RPA (155, 174-176), and quantum dots (177), for the diagnosis of animal pathogens has also been explored. Therefore, the current approach in the development of a desirable FMD diagnostic test typically involves the incorporation of two assays such as RT-LAMP-LFD (46) and RT-RPA-LFD $(155,156)$. Waters et al. (46) modified an existing FMDV RT-LAMP assay to allow detection of LAMP products with LFD by labeling the FIP/BIP at the $5^{\prime}$ terminus with fluorescein (Flc) and biotin (Btn). This RT-LAMP-LFD assay produced concordant results as compared to those obtained using RT-qPCR with a positive detection of FMDV RNA when the FMDV spiked $10 \%$ epithelium suspensions diluted to a range 
TABLE 3 | Lateral flow immunochromatographic (LFI) assays for FMDV diagnosis.

\begin{tabular}{|c|c|c|c|c|c|}
\hline Methods & Description & $\begin{array}{l}\text { Diagnostic } \\
\text { sensitivity }\end{array}$ & $\begin{array}{l}\text { Diagnostic } \\
\text { specificity }\end{array}$ & $\begin{array}{l}\text { Tested clinical } \\
\text { samples }\end{array}$ & References \\
\hline \multirow[t]{3}{*}{ LFD } & $\begin{array}{l}\text { LFDs using guinea pig serotype-specific capture } \\
\text { antibody-gold conjugate were produced for rapid } \\
\text { detection of FMDV serotypes O, A, and Asia 1. Goat } \\
\text { anti-guinea pig antibody and specific antibodies against } \\
\text { FMDV serotypes O, A, and Asia } 1 \text { were blotted on } \\
\text { nitrocellulose membrane as control line and test line, } \\
\text { respectively }\end{array}$ & $88.3-88.7 \%$ & $97.1-98.2 \%$ & $\begin{array}{l}\text { Vesicular epithelia } \\
\text { and fluid from } \\
\text { animals }\end{array}$ & $(144,145)$ \\
\hline & $\begin{array}{l}\text { LFD for detection of FMDV serotypes O, A, Asia 1, and } \\
\text { C. A non-neutralizing monoclonal antibody that } \\
\text { cross-reacts with the FMDV serotypes O, A, Asia 1, and } \\
\text { C was labeled with colloidal gold for detection. The test } \\
\text { and control lines contained the immobilized monoclonal } \\
\text { antibody specific against the antigens, and rabbit } \\
\text { anti-mouse antibody, respectively }\end{array}$ & $87.3 \%$ & $98.8 \%$ & $\begin{array}{l}\text { Epithelial } \\
\text { suspensions }\end{array}$ & (146) \\
\hline & $\begin{array}{l}\text { LFD based on recombinant } 3 A B C \text { to detect anti-NSP } \\
\text { antibodies in infected swine }\end{array}$ & $96.8 \%$ & $98.8-100 \%$ & $\begin{array}{l}\text { Serum samples } \\
\text { from swine }\end{array}$ & (148) \\
\hline Methods & Description & \multicolumn{2}{|c|}{ Detection limit } & $\begin{array}{l}\text { Tested clinical } \\
\text { samples }\end{array}$ & References \\
\hline \multirow[t]{4}{*}{ LFD } & $\begin{array}{l}\text { LFD generated to detect the antibodies directed against } \\
\text { VP1 of FMDV serotype O. The VP1 was conjugated to } \\
\text { colloidal gold as detector, while the capturing } \\
\text { staphylococcal protein A and swine anti-FMDV antibody } \\
\text { were blotted on nitrocellulose membrane for the test and } \\
\text { control lines, respectively }\end{array}$ & \multicolumn{2}{|c|}{$\begin{array}{l}\text { 1:1,280 dilution of a } \\
\text { known titer FMDV } \\
\text { serotype } \\
\text { O-specific antibody }\end{array}$} & $\begin{array}{l}\text { Serum samples of } \\
\text { swine origins }\end{array}$ & (149) \\
\hline & $\begin{array}{l}\text { A multiplex LFD for simultaneous detection and } \\
\text { identification of FMDV serotypes O, A, and Asia 1. A } \\
\text { cocktail of gold-labeled monoclonal antibodies reacted } \\
\text { to the test samples in a separate tube. The multiplex LFD } \\
\text { device was dipped into the mixture samples and FMDV } \\
\text { of each serotype was detected by the serotype-specific } \\
\text { antibodies on the three test lines. The control line } \\
\text { contained anti-mouse antibody }\end{array}$ & \multicolumn{2}{|c|}{ - $17-7,200$ viral particles } & $\begin{array}{l}\text { Tissues } \\
\text { suspensions } \\
\text { (tongues, foot } \\
\text { lesion, coronary } \\
\text { band, and heart) } \\
\text { and swabs } \\
\text { collected from } \\
\text { ruptured lesions of } \\
\text { the infected } \\
\text { animals }\end{array}$ & (151) \\
\hline & $\begin{array}{l}\text { LFD utilized for the detection of antibodies against } \\
\text { recombinant NSP (part of the } 2 \text { C fused to } 3 \text { AB) of FMDV. } \\
\text { The recombinant NSP was labeled with colloidal gold for } \\
\text { use as detector. The test and control lines contained the } \\
\text { recombinant NSP antigen and rabbit antirecombinant } \\
\text { NSP antibody, respectively. }\end{array}$ & \multicolumn{2}{|c|}{$\begin{array}{l}\text { - } 1: 32 \text { to } 1: 64 \text { dilution of } \\
\text { sera samples }\end{array}$} & $\begin{array}{l}\text { Serum samples } \\
\text { from pigs, cattle, } \\
\text { sheep }\end{array}$ & (152) \\
\hline & $\begin{array}{l}\text { LFD that utilizes serotype-specific biotinylated } \\
\text { monoclonal antibody as capture antibody and } \\
\text { serotype-independent monoclonal antibody labeled with }\end{array}$ & \multicolumn{2}{|c|}{$\begin{array}{l}\text { - } 2.55-6.3 \log _{10} \mathrm{TCID}_{50} / \mathrm{mL} \\
\text { of FMDV }\end{array}$} & $\begin{array}{l}\text { Vesicular fluid and } \\
\text { epithelial samples, } \\
\text { and swabs }\end{array}$ & (153) \\
\hline
\end{tabular}


TABLE 3 | Continued

\begin{tabular}{|c|c|c|c|c|}
\hline Methods & Description & Detection limit & $\begin{array}{l}\text { Tested clinical } \\
\text { samples }\end{array}$ & References \\
\hline & $\begin{array}{l}\text { colloidal gold for detection. The test and control lines } \\
\text { contained the biotin-binding protein and anti-mouse } \\
\text { antibody, respectively. This assay detected FMDV } \\
\text { serotypes O, A, and Asia. }\end{array}$ & & $\begin{array}{l}\text { collected over the } \\
\text { lesion areas from } \\
\text { animals }\end{array}$ & \\
\hline & $\begin{array}{l}\text { A multiplex LFD that detected all seven serotypes of } \\
\text { FMDV and concurrently distinguished serotypes O, A, C } \\
\text { and Asia 1. A serotype-independent monoclonal } \\
\text { antibody, 1H5, was labeled with colloidal gold for } \\
\text { detection. Each serotype-specific monoclonal antibody } \\
\text { and } 1 \mathrm{H} 5 \text { were blotted on different test lines on } \\
\text { nitrocellulose membrane as capture antibodies. The } \\
\text { control line contained the anti-mouse antibody }\end{array}$ & $\begin{array}{l}\text { - } 10^{3} \text { to } 10^{4} \mathrm{TCID}_{50} \\
\text { of FMDV }\end{array}$ & $\begin{array}{l}\text { Vesicular fluids, } \\
\text { vesicular epithelial } \\
\text { emulsions and oral } \\
\text { and/or nasal } \\
\text { swabs from pigs }\end{array}$ & $(154)$ \\
\hline \multirow[t]{2}{*}{ RT-RPA-LFD } & $\begin{array}{l}\text { A combination of RT-RPA and lateral flow dipstick for } \\
\text { detecting and serotyping FMDV O, A, and Asia 1. The } \\
\text { probes and primers used in RT-RPA were labeled with } \\
\text { fluorescein and biotin, respectively, to enable detection in } \\
\text { LFD. }\end{array}$ & - 50 copies of viral RNA & $\begin{array}{l}\text { Vesicular material, } \\
\text { saliva, aerosol, } \\
\text { esophageal- } \\
\text { pharyngeal fluid, } \\
\text { blood, and nasal } \\
\text { swab samples } \\
\text { from animals }\end{array}$ & (155) \\
\hline & $\begin{array}{l}\text { RT-RPA-LFD assay performed without equipment but } \\
\text { body heat (in a closed fist). The assay detected FMDV } \\
\text { serotypes O, A, and Asia in } 17 \text { min. The probes and } \\
\text { primers used in RT-RPA were labeled with fluorescein } \\
\text { and biotin, respectively, to enable detection in LFD }\end{array}$ & $\begin{array}{l}\text { - } 100 \text { copies of in vitro } \\
\text { transcribed FMDV RNA }\end{array}$ & $\begin{array}{l}\text { Vesicular fluid and } \\
\text { epithelial tissue } \\
\text { samples collected } \\
\text { from pigs. Serum } \\
\text { samples of bovine } \\
\text { origin }\end{array}$ & (156) \\
\hline $\begin{array}{l}\text { RT-LAMP- } \\
\text { LFD }\end{array}$ & $\begin{array}{l}\text { RT-LAMP coupled to LFD for improved detection of } \\
\text { FMDV. The primers used in RT-LAMP were labeled with } \\
\text { fluorescein and biotin to enable detection in LFD. This } \\
\text { assay enables detection of FMDV without nuclei acid } \\
\text { extraction step }\end{array}$ & $\begin{array}{l}\text { - } 10^{-5} \text { dilution of } \\
\text { FMDV-infected } \\
\text { epithelial suspensions }\end{array}$ & $\begin{array}{l}\text { Epithelial } \\
\text { suspension and air } \\
\text { samples from pig, } \\
\text { cattle, and sheep }\end{array}$ & $(46)$ \\
\hline
\end{tabular}

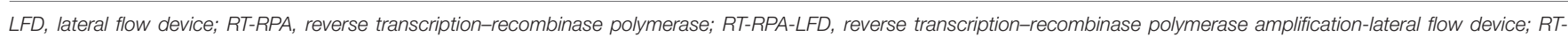

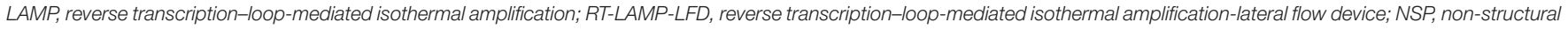
protein; RNA, ribonucleic acid; TCID $50,50 \%$ tissue culture infectious dose.

of $10^{-5}$. The RT-LAMP-LFD assay also showed $10^{4}$ times more sensitive in detecting FMDV than most of the FMD-specific antigen lateral flow devices. Hence, this assay not only resolved the problem of relatively low analytical sensitivity encountered by most LFD used in the field, but it also detected FMDV RNA in the raw epithelial suspension (in the absence of RNA extraction) by only diluting the samples with nuclease-free water and incubating the mixture using a water bath set at $60^{\circ} \mathrm{C}$ for RT-LAMP amplification. With its ideal characteristics, this LFD assay serves as a "proof of concept" for the future use of LAMP in the development of a pen-side assay for FMDV. However, the difficulty in designing the four to six primers needed in RT-LAMP, especially in a virus like FMDV that exhibits a high mutation rate during its replication, hinders the usage of RTLAMP-LFD assay. In addition, the incubation for RT-LAMP for 45 to $60 \mathrm{~min}$ is disadvantageous compared to an RT-RPA approach with a run time of only 4 to $10 \mathrm{~min}$ (14). As described earlier, as an isothermal DNA amplification method, RPA has been widely used in the detection of different pathogens. Wang et al. (155) established a combination method of RT-RPA and lateral flow dipstick (RT-RPA-LFD) for detecting and serotyping of FMDV in the field. They constructed a recombinant vector, pcDNA3.1-2B, containing the $2 B$ gene of FMDV, and amplified it with RT-RPA using specific primers and a probe within $20 \mathrm{~min}$. The newly established FMDV RT-RPA-LFD assay has a higher sensitivity, up to 10 copies as compared with the previous FMDV RT-RPA assays $(14,40)$ with sensitivity limited to 100 RNA copies. Furthermore, this RT-RPA-LFD assay only requires a thermos metal bath at $38^{\circ} \mathrm{C}$ unlike other previous RT-RPA assays, which need a sophisticated instrumentation, and the RPA amplicons can be detected by LFD within $5 \mathrm{~min}$. The RTRPA-LFD is a promising POC diagnostic test for FMDV as it reacts with the FMDV reference strains, including serotypes $\mathrm{O}$, A, and Asia 1, and with no cross-reactivity with other viral pathogens from cattle, which had similar vesicular lesions and clinical symptoms. At the same time, another FMDV RPALFD assay that targets the VP1 gene was also developed by the same research group (178). VP1 protein has been widely used to determine the genetic relationships between different strains of FMDV because of its high genetic heterogeneity (179). 
Therefore, primers and probes specific for serotypes $\mathrm{O}, \mathrm{A}$, and Asia 1 of FMDV were designed based on the alignment of the VP1 nucleotide sequences. The detection limits of these assays were three copies of plasmid DNA or 50 copies of viral RNA with $98.41 \%$ concordance between the RT-RPA-LFD and RTqPCR assays. The development of this serotype-specific RT-RPALFD assay provides a rapid, sensitive, and specific method for differentiation of FMDV serotypes A, O, or Asia 1. On the other hand, an equipment-free FMDV RPA-LFD specifically designed for the $3 D$ gene was also developed by Liu et al. (156). They performed the assay by incubating the reaction tubes in a closed fist using body heat for $15 \mathrm{~min}$. The developed RPA-LFD was capable to detect FMDV serotypes O, A, and Asia 1 using 10 ng viral RNA and DNA as templates with no cross-detections observed. The analytical sensitivity was equivalent to RT-qPCR with 100 copies of in vitro-transcribed FMDV RNA per reaction. One of the benefits in their work is the instant utilization of FMDV RNA as the template in the RPA-LFD without the need to reverse-transcribe the viral RNA into CDNA as required in other RPA assays. This rapid, visible and equipment-free method makes FMDV RPA-LF assay ideal for reliable detection of FMDV in an underequipped laboratory and at point of need, especially in low-resource settings.

\section{FMD-DIAGNOSTIC ASSAYS FOR THE PROGRESSIVE CONTROL OF FMD}

Over the past decades, livestock industry has developed remarkably, contributing $40 \%$ of the global value of agricultural output and, sustaining the food security of almost 1.3 billion people $(180,181)$. However, outbreaks of animal diseases remain a major concern that threatens the livestock industry. Footand-mouth disease, as one of the most significant animal diseases, poses a severe constraint on the reduction of poverty in countries where this disease is endemic and more prone to food insecurity. Contingency plans for an FMD emergency enable rapid detection of the virus before it progresses to an epidemic outbreak (182). Current laboratory approaches for FMD diagnosis are generally based on assays that exploit the clinical windows of infected animals. The diagnostic window is typically 2 to 14 days with an early observation of clinical signs from vesicular lesions. Rapid confirmation includes assays that aim to detect FMDV in vesicular epithelium and vesicular fluid from clinical lesions, as well as in the blood and mucosal swabs from the active surveillance of infected animals in preclinical cases. Furthermore, FMDV-specific antibody responses can also be detected by serological assays in animals exposed to and recovered from FMDV.

Foot-and-mouth disease diagnosis is performed at two levels: (i) in the field/local and (ii) in the central laboratory. If there is a suspected case of FMD in the field, a quick diagnosis is performed by the FMD diagnostic specialist in order to implement immediate control or biosecurity measures. Clinical examinations and collection of suspected animal's history are performed for epidemiological and disease prevalence investigations. In addition, a range of specimens that might be included in the differential diagnosis is collected and transported back to the regional or central laboratory for further examination. These specimens consist of (i) oral swabs from ruptured lesions; (ii) nasal swabs from lesion less than a week old, where vesicular material is not available; (iii) vesicular fluid from unruptured vesicles; (iv) epithelium from ruptured tissues, placed in a neutral buffer phosphate saline with 50\% glycerol; and (v) blood specimens from suspected cases. Although proband samples are not recommended for the first-line diagnostic tests, the oropharyngeal fluid is collected if no fresh lesions are detected. All samples in the ideally leakproof transport containers are labeled and stored in an insulated cool box with a submission form with case history sealed in an external disinfectant see-through bag with photographs of infected animals. The assessment of the situation on the field, and steps taken to secure a confirmatory diagnosis must be immediately reported to the state or regional and central veterinary officers for further advices regarding the disease control strategies.

The subsequent diagnosis of FMD generally depends on the laboratory testing, which includes live virus isolation from tissue culture coupled with the identification of the viral antigen by ELISA or detection of the viral nucleic acid by RT-PCR. Detection of elevated FMD-specific antibodies by ELISA or VNT may also aid in indicating a recovery from the virus infection. These diagnostic assays were performed at a regional or central laboratory to prescribe appropriate control measures based on the confirmation of a definitive diagnosis (168). Hence, these tests should be highly sensitive and specific to provide a differential diagnosis. In the central laboratory, virus and its viral components can be detected with various diagnostic assays. These assays include VI, Ag-ELISA, multiplex RT-PCR, RT-qPCR, and nucleotide sequencing. In addition, antiviral antibodies against SPs can also be detected using VNT, LPB sandwich ELISA, and SPCE-ELISA, whereas antibodies against NSPs can be detected using $3 \mathrm{ABC}$-ELISA. The detailed diagnoses performed at the central laboratory enable the confirmation of disease, serotyping of virus, molecular epidemiology, and phylogenetic analysis and lastly determined the most relevant vaccine matching strains to control an outbreak (183). The performance of all these assays varies in terms of sensitivity, specificity, and time required. The speed of a definitive diagnosis would vary depending on the distance of the samples being transported from the field to an appropriate laboratory. Thus, a network of international reference laboratories and collaborating centers is essential for handling of specimens in the event of a large outbreak, for the purpose of both surveillance and rapid diagnosis. Scalability and cost of each assay must also be taken into consideration especially in FMD endemic and underdeveloped countries. The establishment of centralized facilities for testing, together with the implementation of quality control systems, have improved significantly the assays for routine diagnostic purposes.

More recently, portable tests or POC diagnostics, such as LFD, mobile PCR, and isothermal assays, have been developed to increase the applicability of these assays in multiple field conditions where rapid screening is of paramount importance. Even though LFD can be operated by "non-specialist," the usage 
of this portable test may be restricted by its low-throughput assay performance. A commercially available LFI strip known as the Svanodip FMDV-Ag LFD by Boehringer Ingelheim Svanova (Sweden) was reported to show similar assay performance to laboratory-based Ag-ELISA when it was applied on the field during the 2007 UK outbreaks (166). The deployment of LFD on field remains advantageous for FMD endemic countries as compared with portable RT-qPCR in terms of production cost $(25,184)$. Although these simple-to-use POC tests offer a rapid result that can support the local decisions, they are also limited by the cost-benefit analysis. In conclusion, the deployment of these portable tests on the field will be taken into consideration after their characteristics have been thoroughly evaluated in terms of test performance, speed, cost, simplicity, and robustness.

The control of FMD varies among countries, depending on the FMD status. As the FMD control in FMD-free countries emphasizes on reducing the risk and impact of the virus incursions from both neighboring and trade-partner countries, the control policies in FMD-free countries have been based on depopulation of infected and in-contact animals, together with restrictions on movement of animals and their products. Early detection followed by surveillance is crucial. In order to regain the international trading rights, FMD-free countries are required to identify the remaining sources of infection and to demonstrate that they are free of the disease. On the other hand, FMD control in endemic countries is implemented by diagnoses, surveillance, and regular mass vaccinations. Most importantly, there is a continuous need for an up-scaling of improved quality vaccines with longer-lasting protection at a lower cost (185). In this context, serological assays including ELISA for detection of antibodies against FMDV SPs and NSPs are used. The former is useful to measure the vaccine efficacy, and the latter is generally used to establish prevalence and to monitor virus circulation as it can detect the presence of the infection regardless of the vaccination status of the animals $(186,187)$. The SP tests are serotype specific. Therefore, virus and antigen closely related to the field strain are selected to be used in ELISA for optimal sensitivity. To date, the commercially available PrioCHECK ${ }^{\circledR}$ FMDV type-specific products by Prionics can only detect antiSP antibodies of 3 FMDV serotypes: O, A, and Asia. Hence, determination of the serotype involved in field outbreaks is important for a proper control of the disease. On the other hand, the use of NSP tests in FMD endemic countries is complicated by the fact that the vaccinated animals may seroconvert after repeated vaccinations. Anti-NSP antibody responses may also be delayed in cases of subclinical or mild clinical infections following routine vaccinations. Moreover, anti-NSP antibodies can persist for a long period and may not indicate a recent FMDV infection $(134,188)$.

The breakthrough of molecular diagnostics along with the development of pen-side devices has allowed the determination of the FMDV serotypes. For endemic countries, the use of LFD is more favorable. A routine screening with an LFD device has been viewed as a rapid and economical tool to determine incidences of the infection in countries where the emergence rate of FMDV is high, under limited-resources veterinary settings.
Therefore, rapid action is needed to minimize the virus spread. As mentioned earlier, serotype-specific LFI test strips can be used for rapid detection and identification of various FMDV serotypes (144, 145, 147, 149, 150, 164). By identifying these FMDV serotypes, appropriate commercial FMD vaccine can be applied to the animal population to minimize the loss of productivity in majority of the smallholder and commercial farmer settings in endemic countries. As for FMD-free countries, confirmatory tests such as ELISA and RT-qPCR are more desirable. Due to the occurrence of FMDV is relatively much lower in these countries, confirmation of the disease is more important than rapid identification of the virus to avoid unnecessary culling of suspected animals. Setup of RT-qPCR in the regional laboratories in these more developed countries, which are typically FMDfree, can increase the diagnostic capacity and subsequently reduce the sample shipping times during a sudden outbreak. The FMD outbreak confirmation along with the virus typing and characterizations enables the study of the virus lineage and routes of transmission, which will provide substantial information for epidemiology study in the effort to control the spread of FMD.

\section{CONCLUSIONS}

The deployment of diagnostic tools to rapidly identify and confirm initial clinical symptoms of an infection is prerequisite in any epidemic disease control strategy, particularly when it comes to the prevalence of the FMDV in a livestock population. As the FMDV infection is clinically indistinguishable from infections resulting from other similar vesicular disease viruses, early diagnosis is critical for efficient disease control. Various diagnostic methods ranging from conventional such as virus isolation and competitive- and blocking-antigen ELISA to molecular-based methods such as RT-PCR and RT-LAMP have been developed over the years. Although ELISA-based methods have good diagnostic sensitivity and specificity, molecular detection methods have the advantage of higher analytical sensitivity for the detection of minimal viral RNA. Despite these accurate and reliable FMDV assays, researchers have been developing alternatives methods that allow for pen-side testing in an attempt to overcome some of the practical challenges such as tedious procedures and the availability of an equipped laboratory setting with trained field personnel. Development of lateral flow devices and integration of the portable RT-PCR, RT-LAMP, and RT-RPA with LF technologies have been made to increase the sensitivity of FMDV detection. Nevertheless, translations of these assays from laboratories to practical applications in the field remain limited, and various technical and cost issues need to be addressed to develop a more flexible and affordable diagnostic tools that can be widely used for FMDV detection.

\section{AUTHOR CONTRIBUTIONS}

$\mathrm{CW}$, CY, and $\mathrm{HO}$ wrote the manuscript. CW, CY, $\mathrm{HO}, \mathrm{KH}$, and $\mathrm{WT}$ approved its final version. All 
authors contributed to the article and approved the submitted version.

\section{FUNDING}

This study was supported by the Ministry of Agriculture and Agro-based Industry, Malaysia (Grant no: 05-01-04-SF1149) and
UPM Putra Grant (grant no: GP-IPS/2017/9539500) of Universiti Putra Malaysia.

\section{ACKNOWLEDGMENTS}

CW was financially supported by MyPhD under the MyBrain 15 programme from the Ministry of Higher Education of Malaysia.

\section{REFERENCES}

1. Kitching RP, Alexandersen S. Clinical variation in foot and mouth disease: pigs. Rev Sci Tech. (2003) 21:513-8. doi: 10.20506/rst.21.3.1367

2. OIE. Foot \& Mouth Disease (FMD) [Online] (2018). Available online at: http://www.oie.int/en/animal-health-in-the-world/animal-diseases/Footand-mouth-disease/ (accessed June 13, 2020).

3. Mowat GN, Darbyshire JH, Huntley JF. Differentiation of a vesicular disease of pigs in Hong Kong from foot-and-mouth disease. Vet Rec. (1972) 90:61821. doi: $10.1136 / v r .90 .22 .618$

4. Fernández J, Agüero M, Romero L, Sánchez C, Belák S, Arias M, et al. Rapid and differential diagnosis of foot-and-mouth disease, swine vesicular disease, and vesicular stomatitis by a new multiplex RT-PCR assay. J Virol Methods. (2008) 147:301-11. doi: 10.1016/j.jviromet.2007.09.010

5. Smith PF, Howerth EW, Carter D, Gray EW, Noblet R, Berghaus RD, et al. Host predilection and transmissibility of vesicular stomatitis New Jersey virus strains in domestic cattle (Bos taurus) and swine (Sus scrofa). BMC Vet Res. (2012) 8:183. doi: 10.1186/1746-6148-8-183

6. Vangrysperre W, De Clercq K. Rapid and sensitive polymerase chain reaction based detection and typing of foot-and-mouth disease virus in clinical samples and cell culture isolates, combined with a simultaneous differentiation with other genomically and/or symptomatically related viruses. Arch Virol. (1996)141:331-44.

7. Baxi MK, Baxi S, Clavijo A, Burton KM, Deregt D. Microarray-based detection and typing of foot-and-mouth disease virus. Vet J. (2006) 172:47381. doi: 10.1016/j.tvjl.2005.07.007

8. Banér J, Gyarmati P, Yacoub A, Hakhverdyan M, Stenberg J, Ericsson O, et al. Microarray-based molecular detection of foot-and-mouth disease, vesicular stomatitis and swine vesicular disease viruses, using padlock probes. J Virol Methods. (2007) 143:200-6. doi: 10.1016/j.jviromet.2007.03.004

9. Lung O, Fisher M, Beeston A, Hughes KB, Clavijo A, Goolia $M$, et al. Multiplex RT-PCR detection and microarray typing of vesicular disease viruses. J Virol Methods. (2011) 175:236-45. doi: 10.1016/j.jviromet.2011.05.023

10. Dill V, Beer M, Hoffmann B. Simple, quick and cost-efficient: a universal RT-PCR and sequencing strategy for genomic characterisation of foot-and-mouth disease viruses. J Virol Methods. (2017) 246:58-64. doi: 10.1016/j.jviromet.2017.04.007

11. Nishi T, Kanno T, Shimada N, Morioka K, Yamakawa M, Fukai K. Reverse transcription-PCR using a primer set targeting the 3D region detects footand-mouth disease virus with high sensitivity. Transbound Emerg Dis. (2019) 66:1776-83. doi: 10.1111/tbed.13202

12. Ambagala A, Fisher M, Goolia M, Nfon C, Furukawa-Stoffer T, Ortega Polo $\mathrm{R}$, et al. Field-deployable reverse transcription-insulated isothermal PCR (RT-iiPCR) assay for rapid and sensitive detection of foot-and-mouth disease virus. Transbound Emerg Dis. (2017) 64:1610-23. doi: 10.1111/tbed.12554

13. Pinheiro-de-Oliveira TF, Fonseca AA Jr, Camargos MF, LaguardiaNascimento M, de Oliveira AM, Cottorello ACP, et al. Development of a droplet digital RT-PCR for the quantification of foot-and-mouth virus RNA. J Virol Methods. (2018) 259:129-34. doi: 10.1016/j.jviromet.2018.06.015

14. Abd El Wahed A, El-Deeb A, El-Tholoth M, Abd El Kader H, Ahmed A, Hassan S, et al. A portable reverse transcription recombinase polymerase amplification assay for rapid detection of foot-and-mouth disease virus. PLoS ONE. (2013) 8:e71642. doi: 10.1371/journal.pone.0071642

15. Reid SM, Mioulet V, Knowles NJ, Shirazi N, Belsham GJ, King DP. Development of tailored real-time RT-PCR assays for the detection and

differentiation of serotype $\mathrm{O}, \mathrm{A}$ and Asia-1 foot-and-mouth disease virus lineages circulating in the Middle East. J Virol Methods. (2014) 207:146-53. doi: 10.1016/j.jviromet.2014.07.002

16. Vandenbussche F, Lefebvre DJ, De Leeuw I, Van Borm S, De Clercq K. Laboratory validation of two real-time RT-PCR methods with 5'-tailed primers for an enhanced detection of foot-and-mouth disease virus. $J$ Virol Methods. (2017) 246:90-4. doi: 10.1016/j.jviromet.2017.04.014

17. Rios L, Perera CL, Coronado L, Relova D, Alvarez AM, Ganges L, et al. Multi-target strategy for pan/foot-and-mouth disease virus (FMDV) detection: a combination of sequences analysis, in silico predictions and laboratory diagnostic evaluation. Front Vet Sci. (2018) 5:160. doi: 10.3389/fvets.2018.00160

18. Goller KV, Dill V, Madi M, Martin P, Van der Stede Y, Vandenberge V, et al. Rapid and simple detection of foot-and-mouth disease virus: evaluation of a cartridge-based molecular detection system for use in basic laboratories. Transbound Emerg Dis. (2018) 65:578-84. doi: 10.1111/tbed.12744

19. Hole K, Nfon C. Foot-and-mouth disease virus detection on a handheld real-time polymerase chain reaction platform. Transbound Emerg Dis. (2019) 66:1789-95. doi: 10.1111/tbed.13227

20. Armson B, Mioulet V, Doel C, Madi M, Parida S, Lemire KA, et al. Detection of foot-and-mouth disease virus in milk samples by real-time reverse transcription polymerase chain reaction: optimisation and evaluation of a high-throughput screening method with potential for disease surveillance. Vet Microbiol. (2018) 223:189-94. doi: 10.1016/j.vetmic.2018.07.024

21. Armson B, Wadsworth J, Kibona T, Mshanga D, Fowler VL. Opportunities for enhanced surveillance of foot-and-mouth disease in endemic settings using milk samples. Transbound Emerg Dis. (2019) 66:1405-10. doi: $10.1111 /$ tbed.13146

22. Erickson A, Fisher M, Furukawa-Stoffer T, Ambagala A, Hodko D, Pasick J, et al. A multiplex reverse transcription PCR and automated electronic microarray assay for detection and differentiation of seven viruses affecting swine. Transbound Emerg Dis. (2018) 65:e272-83. doi: 10.1111/tbed.12749

23. Chen HT, Zhang J, Liu YS, Liu XT. Rapid typing of foot-and-mouth disease serotype Asia 1 by reverse transcription loop-mediated isothermal amplification. Virol J. (2011) 8:489. doi: 10.1186/1743-422x-8-489

24. Ding Y-Z, Zhou J-H, Ma L-N, Qi Y-N, Wei G, Zhang J, et al. A reverse transcription loop-mediated isothermal amplification assay to rapidly diagnose foot-and-mouth disease virus C. J Vet Sci. (2014) 15:423-6. doi: $10.4142 /$ jvs.2014.15.3.423

25. Yamazaki W, Mioulet V, Murray L, Madi M, Haga T, Misawa N, et al. Development and evaluation of multiplex RT-LAMP assays for rapid and sensitive detection of foot-and-mouth disease virus. J Virol Methods. (2013) 192:18-24. doi: 10.1016/j.jviromet.2013.03.018

26. Lim DR, Kim HR, Park MJ, Chae HG, Ku BK, Nah JJ, et al. An improved reverse transcription loop-mediated isothermal amplification assay for sensitive and specific detection of serotype $\mathrm{O}$ foot-and-mouth disease virus. J Virol Methods. (2018) 260:6-13. doi: 10.1016/j.jviromet.2018.06.017

27. Ranjan R, Kangayan M, Subramaniam S, Mohapatra JK, Biswal JK, Sharma GK, et al. Development and evaluation of a one step reverse transcription-loop mediated isothermal amplification assay (RT-LAMP) for rapid detection of foot and mouth disease virus in India. Virus Dis.(2014) 25:358-64. doi: 10.1007/s13337-014-0211-2

28. Howson ELA, Armson B, Madi M, Kasanga CJ, Kandusi S, Sallu R, et al. Evaluation of two lyophilized molecular assays to rapidly detect footand-mouth disease virus directly from clinical samples in field settings. Transbound Emerg Dis. (2017) 64:861-71. doi: 10.1111/tbed.12451 
29. Farooq U, Latif A, Irshad H, Ullah A, Zahu AB, Naeem K, et al. Loopmediated isothermal amplification (RT-LAMP): a new approach for the detection of foot-and-mouth disease virus and its sero-types in Pakistan. Iran $J$ Vet Res. (2015) 16:331-4.

30. Guan H, Li Z, Yin X, Zhang Y, Gao P, Bai Y, et al. Rapid detection and differentiation of foot and mouth disease virus serotypes by antigen-capture reverse transcriptase loop-mediated isothermal amplification. Asian J Anim Vet Adv. (2013) 8:647-54. doi: 10.3923/ajava.2013.647.654

31. Madhanmohan M, Nagendrakumar SB, Manikumar K, Yuvaraj S, Parida $S$, Srinivasan VA. Development and evaluation of a real-time reverse transcription-loop-mediated isothermal amplification assay for rapid serotyping of foot-and-mouth disease virus. J Virol Methods. (2013) 187:195202. doi: 10.1016/j.jviromet.2012.08.015

32. Meyer RF, Brown CC, House C, House JA, Molitor TW. Rapid and sensitive detection of foot-and-mouth disease virus in tissues by enzymatic RNA amplification of the polymerase gene. J Virol Methods. (1991) 34:161-72. doi: 10.1016/0166-0934(91)90096-I

33. Höfner MC, Carpenter WC, Donaldson AI. Detection of foot-andmouth disease virus RNA in clinical samples and cell culture isolates by amplification of the capsid coding region. J Virol Methods. (1993) 42:53-61. doi: 10.1016/0166-0934(93)90176-R

34. Laor O, Torgersen H, Yadin H, Becker Y. Detection of FMDV RNA amplified by the polymerase chain reaction (PCR). J Virol Methods. (1992) 36:197-207. doi: 10.1016/0166-0934(92)90051-E

35. Smith CJ, Osborn AM. Advantages and limitations of quantitative PCR (Q-PCR)-based approaches in microbial ecology. FEMS Microbiol Ecol. (2009) 67:6-20. doi: 10.1111/j.1574-6941.2008.00629.x

36. Moonen P, Boonstra J, van der Honing RH, Leendertse CB, Jacobs L, Dekker A. Validation of a LightCycler-based reverse transcription polymerase chain reaction for the detection of foot-and-mouth disease virus. J Virol Methods. (2003) 113:35-41. doi: 10.1016/s0166-0934(03)00220-9

37. Callahan JD, Brown F, Osorio FA, Sur JH, Kramer E, Long GW, et al. Use of a portable real-time reverse transcriptase-polymerase chain reaction assay for rapid detection of foot-and-mouth disease virus. J Am Vet Med Assoc. (2002) 220:1636-42. doi: 10.2460/javma.2002.220.1636

38. Reid SM, Ferris NP, Hutchings GH, Zhang Z, Belsham GJ, Alexandersen S. Detection of all seven serotypes of foot-and-mouth disease virus by real-time, fluorogenic reverse transcription polymerase chain reaction assay. J Virol Methods. (2002) 105:67-80. doi: 10.1016/S0166-0934(02)00081-2

39. El-Shehawy L, Abu-Elnaga H, Abdel AM, Fawzy H, Al-Watany H, Azab A. Laboratory diagnosis of FMD using real-time RT-PCR in Egypt. Life Sci J. (2011) 8:384-7.

40. Howson ELA, Kurosaki Y, Yasuda J, Takahashi M, Goto H, Gray AR, et al. Defining the relative performance of isothermal assays that can be used for rapid and sensitive detection of foot-and-mouth disease virus. J Virol Methods. (2017) 249:102-10. doi: 10.1016/j.jviromet.2017.08.013

41. Fontél KS, Botner A, Belsham GJ, Lohse L. Diagnostic comparison of serum and EDTA-stabilized blood samples for the detection of foot-andmouth disease virus RNA by RT-qPCR. J Virol Methods. (2019) 270:120-5. doi: 10.1016/j.jviromet.2019.05.003

42. Notomi T, Okayama H, Masubuchi H, Yonekawa T, Watanabe K, Amino $\mathrm{N}$, et al. Loop-mediated isothermal amplification of DNA. Nucleic Acids Res. (2000) 28:E63. doi: 10.1093/nar/28.12.e63

43. Mori Y, Nagamine K, Tomita N, Notomi T. Detection of loop-mediated isothermal amplification reaction by turbidity derived from magnesium pyrophosphate formation. Biochem Biophys Res Commun. (2001) 289:150-4. doi: 10.1006/bbrc.2001.5921

44. Dukes JP, King DP, Alexandersen S. Novel reverse transcription loop-mediated isothermal amplification for rapid detection of foot-and-mouth disease virus. Arch Virol. (2006) 151:1093-106. doi: 10.1007/s00705-005-0708-5

45. Li J, Chen Q, Xiong W, Fang XE. [Establishment of RT- LAMP for rapid detection of foot-and-mouth disease virus]. Bing Du Xue Bao. (2009) 25:13742 .

46. Waters RA, Fowler VL, Armson B, Nelson N, Gloster J, Paton DJ, et al. Preliminary validation of direct detection of foot-and-mouth disease virus within clinical samples using reverse transcription loopmediated isothermal amplification coupled with a simple lateral flow device for detection. PLoS ONE. (2014) 9:e105630. doi: 10.1371/journal.pone. 0105630

47. Maryam S, Rashid T, Latif A, Zahra R, Bin Zahur A, Ahsan A, et al. One-step real-time loop-mediated isothermal amplification (RT-LAMP): evaluation and its application for the detection of foot-and-mouth-disease virus and its serotypes. Turk J Vet. Anim. Sci. (2017) 41:435-43. doi: 10.3906/vet-1611-10

48. Gadkar VJ, Goldfarb DM, Gantt S, Tilley PAG. Real-time detection and monitoring of loop mediated amplification (LAMP) reaction using selfquenching and de-quenching fluorogenic probes. Sci Rep. (2018) 8:5548. doi: 10.1038/s41598-018-23930-1

49. Kasanga CJ, Yamazaki W, Mioulet V, King DP, Mulumba M, Ranga E, et al. Rapid, sensitive and effective diagnostic tools for foot-andmouth disease virus in Africa. Onderstepoort J Vet Res. (2014) 81:E1-5. doi: 10.4102/ojvr.v81i2.727

50. Pega J, Bucafusco D, Di Giacomo S, Schammas JM, Malacari D, Capozzo $\mathrm{AV}$, et al. Early adaptive immune responses in the respiratory tract of foot-and-mouth disease virus-infected cattle. J Virol. (2013) 87:2489-95. doi: 10.1128/jvi.02879-12

51. Senthilkumaran C, Yang M, Bittner H, Ambagala A, Lung O, Zimmerman J, et al. Detection of genome, antigen, and antibodies in oral fluids from pigs infected with foot-and-mouth disease virus. Can J Vet Res. (2017) 81:82-90.

52. Wong CL, Sieo CC, Tan WS. Display of the VP1 epitope of foot-and-mouth disease virus on bacteriophage $\mathrm{T} 7$ and its application in diagnosis. J Virol Methods. (2013) 193:611-9. doi: 10.1016/j.jviromet.2013.07.053

53. Wong CL, Yong CY, Muhamad A, Syahir A, Omar AR, Sieo CC, et al. A 12-residue epitope displayed on phage $\mathrm{T} 7$ reacts strongly with antibodies against foot-and-mouth disease virus. Appl Microbiol Biotechnol. (2018) 102:4131-42. doi: 10.1007/s00253-018-8921-9

54. Cao Y, Lu Z, Li Y, Sun P, Li D, Li P, et al. Poly(I:C) combined with multi-epitope protein vaccine completely protects against virulent footand-mouth disease virus challenge in pigs. Antiviral Res. (2013) 97:145-53. doi: 10.1016/j.antiviral.2012.11.009

55. Cao Y, Zhou W, Xing X, Zhang J, Fu Y, Li K, et al. Indirect ELISA using a multi-epitope recombinant protein to detect antibodies against foot-andmouth disease virus serotype O in pigs. J Virol Methods. (2018) 262:26-31. doi: 10.1016/j.jviromet.2018.09.008

56. Hosamani M, Basagoudanavar SH, Tamil Selvan RP, Das V, Ngangom P, Sreenivasa BP, et al. A multi-species indirect ELISA for detection of nonstructural protein $3 \mathrm{ABC}$ specific antibodies to foot-and-mouth disease virus. Arch Virol. (2015) 160:937-44. doi: 10.1007/s00705-015-2339-9

57. Biswal JK, Subramaniam S, Ranjan R, Sharma GK, Misri J, Pattnaik B. Marker vaccine potential of foot-and-mouth disease virus with large deletion in the non-structural proteins 3A and 3B. Biologicals. (2015) 43:504-11. doi: 10.1016/j.biologicals.2015.07.004

58. Bhatt M, Mohapatra JK, Pandey LK, Mohanty NN, Das B, Prusty BR, et al. Mutational analysis of foot and mouth disease virus nonstructural polyprotein $3 \mathrm{AB}$-coding region to design a negative marker virus. Virus Res. (2018) 243:36-43. doi: 10.1016/j.virusres.2017.10.010

59. Muller JD, McEachern JA, Bossart KN, Hansson E, Yu M, Clavijo A, et al. Serotype-independent detection of foot-and-mouth disease virus. J Virol Methods. (2008) 151:146-53. doi: 10.1016/j.jviromet.2008.03.011

60. Veerasami M, Singanallur NB, Thirumeni N, Rana SK, Shanmugham $\mathrm{R}$, Ponsekaran S, et al. Serotyping of foot-and-mouth disease virus by antigen capture-ELISA using monoclonal antibodies and chicken IgY. New Microbiol. (2008) 31:549-54.

61. Ko YJ, Jeoung HY, Lee HS, Chang BS, Hong SM, Heo EJ, et al. A recombinant protein-based ELISA for detecting antibodies to foot-andmouth disease virus serotype Asia 1. J Virol Methods. (2009) 159:112-8. doi: 10.1016/j.jviromet.2009.03.011

62. Chen H-T, Peng Y-H, Zhang Y-G, Liu X-T. Detection of foot-and-mouth disease serotype $\mathrm{O}$ by ELISA using a monoclonal antibody. Monoclon Antib Immunodiagn Immunother. (2013) 32:47-9. doi: 10.1089/mab.2012.0081

63. Sridevi NV, Shukra AM, Neelakantam B, Anilkumar J, Madhanmohan M, Rajan S, et al. Development of anti-bovine IgA single chain variable fragment and its application in diagnosis of foot-and-mouth disease. Eur J Microbiol Immunol. (2014) 4:34-44. doi: 10.1556/EuJMI.4.2014.1.3

64. Ferris NP, Abrescia NG, Stuart DI, Jackson T, Burman A, King DP, et al. Utility of recombinant integrin alpha $\mathrm{v}$ beta 6 as a capture reagent in 
immunoassays for the diagnosis of foot-and-mouth disease. J Virol Methods. (2005) 127:69-79. doi: 10.1016/j.jviromet.2005.02.014

65. Ferris NP, Grazioli S, Hutchings GH, Brocchi E. Validation of a recombinant integrin alphavbeta6/monoclonal antibody based antigen ELISA for the diagnosis of foot-and-mouth disease. J Virol Methods. (2011) 175:253-60. doi: 10.1016/j.jviromet.2011.05.026

66. Shimmon G, Wood BA, Morris A, Mioulet V, Grazioli S, Brocchi E, et al. Truncated bovine integrin alpha-v/beta-6 as a universal capture ligand for FMD diagnosis. PLoS ONE. (2016) 11:e0160696. doi: 10.1371/journal.pone.0160696

67. Chen TH, Lee F, Lin YL, Dekker A, Chung WB, Pan $\mathrm{CH}$, et al. Differentiation of foot-and-mouth disease-infected pigs from vaccinated pigs using antibody-detecting sandwich ELISA. J Vet Med Sci. (2011) 73:977-84. doi: 10.1292/jvms.10-0351

68. Chitray M, Grazioli S, Willems T, Tshabalala T, De Vleeschauwer A, Esterhuysen JJ, et al. Development and validation of a foot-andmouth disease virus SAT serotype-specific $3 \mathrm{ABC}$ assay to differentiate infected from vaccinated animals. J Virol Methods. (2018) 255:44-51. doi: 10.1016/j.jviromet.2018.02.006

69. Fowler VL, Paton DJ, Rieder E, Barnett PV. Chimeric foot-and-mouth disease viruses: evaluation of their efficacy as potential marker vaccines in cattle. Vaccine. (2008) 26:1982-9. doi: 10.1016/j.vaccine.2008.02.012

70. Fowler VL, Knowles NJ, Paton DJ, Barnett PV. Marker vaccine potential of a foot-and-mouth disease virus with a partial VP1 G-H loop deletion. Vaccine. (2010) 28:3428-34. doi: 10.1016/j.vaccine.2010.02.074

71. Morioka K, Fukai K, Yoshida K, Yamazoe R, Onozato H, Ohashi S, et al. Neutralizing monoclonal antibody sandwich liquid-phase blocking enzyme-linked immunosorbent assay for detection of Foot-and-mouth disease virus type O antibodies. J Vet Diagn Invest. (2009) 21:499-503. doi: $10.1177 / 104063870902100411$

72. Robiolo B, La Torre J, Duffy S, Leon E, Seki C, Torres A, et al. Quantitative single serum-dilution liquid phase competitive blocking ELISA for the assessment of herd immunity and expected protection against foot-andmouth disease virus in vaccinated cattle. J Virol Methods. (2010) 166:21-7. doi: 10.1016/j.jviromet.2010.02.011

73. Sharma GK, Mahajan S, Matura R, Subramaniam S, Mohapatra JK, Pattnaik B. Quantitative single dilution liquid phase blocking ELISA for seromonitoring of foot-and-mouth disease in India. Biologicals. (2015) 43:15864. doi: 10.1016/j.biologicals.2015.03.003

74. Ko Y-J, Lee H-S, Jeoung H-Y, Heo E-J, Ko H-R, Chang B-S, et al. Use of a baculovirus-expressed structural protein for the detection of antibodies to foot-and-mouth disease virus type A by a blocking enzymelinked immunosorbent assay. Clin Vaccine Immunol. (2010) 17:194-8. doi: 10.1128/CVI.00374-09

75. Ko YJ, Lee HS, Park JH, Lee KN, Kim SM, Cho IS, et al. Field application of a recombinant protein-based ELISA during the 2010 outbreak of foot-andmouth disease type A in South Korea. J Virol Methods. (2012) 179:265-8. doi: 10.1016/j.jviromet.2011.09.021

76. Dash L, Subramaniam S, Khulape SA, Prusty BR, Pargai K, Narnaware SD, et al. Development and utilization of VHH antibodies derived from camelus dromedarius against foot-and-mouth disease virus. Anim Biotechnol. (2019) 30:57-62. doi: 10.1080/10495398.2018.1433191

77. Li Y, Swabey KG, Gibson D, Keel PJ, Hamblin P, Wilsden G, et al. Evaluation of the solid phase competition ELISA for detecting antibodies against the six foot-and-mouth disease virus non-O serotypes. J Virol Methods. (2012) 183:125-31. doi: 10.1016/j.jviromet.2012.04.002

78. Kang YL, Jeong JY, Choi HY, Zhang Y, Liu Y, Lee HJ, et al. Evaluation and optimization of a conventional SPCE for FMD post-vaccination monitoring. BMC Vet Res. (2018) 14:371. doi: 10.1186/s12917-018-1686-7

79. Biswal JK, Bisht P, Mohapatra JK, Ranjan R, Sanya, A, Pattnaik B. Application of a recombinant capsid polyprotein (P1) expressed in a prokaryotic system to detect antibodies against foot-and-mouth disease virus serotype O.J Virol Methods. (2015) 215-16, 45-51. doi: 10.1016/j.jviromet.2015.02.008

80. Ran X, Yang Z, Bai M, Zhang Y, Wen X, Guo H, et al. Development and validation of a competitive ELISA based on bacterium-original virus-like particles of serotype $O$ foot-and-mouth disease virus for detecting serum antibodies. Appl Microbiol Biotechnol. (2019) 103:3015-24. doi: 10.1007/s00253-019-09680-8
81. Yang $\mathrm{M}, \mathrm{Xu} \mathrm{W}$, Bittner H, Horsington J, Vosloo W, Goolia M, et al. Generation of mAbs to foot-and-mouth disease virus serotype A and application in a competitive ELISA for serodiagnosis. Virol J. (2016) 13:195. doi: 10.1186/s12985-016-0650-z

82. Gelkop S, Sobarzo A, Brangel P, Vincke C, Romao E, Fedida-Metula S, et al. The development and validation of a novel nanobody-based competitive ELISA for the detection of foot and mouth disease $3 \mathrm{ABC}$ antibodies in cattle. Front Vet Sci. (2018) 5:250. doi: 10.3389/fvets.2018.00250

83. Dong Y, Xu Y, Liu Z, Fu Y, Ohashi T, Tanaka Y, et al. Rapid screening swine foot-and-mouth disease virus using micro-ELISA system. Lab Chip. (2011) 11:2153-5. doi: 10.1039/c0lc00678e

84. Dong Y, Xu Y, Liu Z, Fu Y, Ohashi T, Mawatari K, et al. Determination of cattle foot-and-mouth disease virus by micro-ELISA method. Anal Sci. (2014) 30:359-63. doi: 10.2116/analsci.30.359

85. Engvall E, Perlmann P. Enzyme-linked immunosorbent assay, Elisa. 3. Quantitation of specific antibodies by enzyme-labeled anti-immunoglobulin in antigen-coated tubes. J Immunol. (1972) 109:129-35.

86. Coons AH, Creech HJ, Jones RN. Immunological properties of an antibody containing a fluorescent group. Proc Soc Exp Biol Med. (1941) 47:200-2. doi: $10.3181 / 00379727-47-13084 \mathrm{P}$

87. Aydin S. A short history, principles, and types of ELISA, and our laboratory experience with peptide/protein analyses using ELISA. Peptides. (2015) 72:415. doi: 10.1016/j.peptides.2015.04.012

88. Ferris NP, Dawson M. Routine application of enzyme-linked immunosorbent assay in comparison with complement fixation for the diagnosis of foot-and-mouth and swine vesicular diseases. Vet Microbiol. (1988) 16:201-9.

89. Linchongsubongkoch W. OIE Reference Laboratory Reports Activities [Online] (2018). Available online at: https://www.oie.int/ fileadmin/Home/eng/Our_scientific_expertise/reflabreports/2018/ report_586_2018_Foot_and_mouth_disease_THAILAND.pdf?fbclid= IwAR2rn2ds53kkV0KCByhHuyDKVNGfUQcgOYz-sNRcevZqihoaj46N_ FhLymA (accessed June 13, 2020).

90. Abu Elzein EM, Crowther JR. Enzyme-labelled immunosorbent assay techniques in foot-and-mouth disease virus research. J Hyg. (1978) 80:391-9. doi: $10.1017 / \mathrm{s} 0022172400024840$

91. Crowther JR, Abu-el Zein EM. Detection and quantification of foot and mouth disease virus by enzyme labelled immunosorbent assay techniques. J Gen Virol. (1979) 42:597-602. doi: 10.1099/0022-1317-42-3-597

92. Roeder PL, Le Blanc Smith PM. Detection and typing of foot-and-mouth disease virus by enzyme-linked immunosorbent assay: a sensitive, rapid and reliable technique for primary diagnosis. Res Vet Sci. (1987) 43:225-32.

93. Elzein EM, Crowther JR. The specific detection of foot-and-mouth disease virus whole particle antigen (140S) by enzyme labelled immunosorbent assay. J Hyg. (1979) 83:127-34. doi: 10.1017/s0022172400025894

94. Hamblin C, Barnett IT, Hedger RS. A new enzyme-linked immunosorbent assay (ELISA) for the detection of antibodies against foot-and-mouth disease virus. I. Development and method of ELISA. J Immunol Methods. (1986) 93:115-21.

95. Meloen RH, Rowlands DJ, Brown F. Comparison of the antibodies elicited by the individual structural polypeptides of foot-and mouth disease and polio viruses. J Gen Virol. (1979) 45:761-3. doi: 10.1099/0022-1317-45-3-761

96. Meloen RH, Briaire J. A study of the cross-reacting antigens on the intact foot-and-mouth disease virus and its $12 \mathrm{~S}$ Subunits with antisera against the structural proteins. J Gen Virol. (1980) 51(Pt 1):107-16. doi: 10.1099/0022-1317-51-1-107

97. McCullough KC, Crowther JR, Butcher RN. Alteration in antibody reactivity with foot-and-mouth disease virus (FMDV) $146 \mathrm{~S}$ antigen before and after binding to a solid phase or complexing with specific antibody. J Immunol Methods. (1985) 82:91-100.

98. Mackay DK, Bulut AN, Rendle T, Davidson F, Ferris NP. A solidphase competition ELISA for measuring antibody to foot-and-mouth disease virus. J Virol Methods. (2001) 97:33-48. doi: 10.1016/s0166-0934(01) 00333-0

99. Tekleghiorghis T, Weerdmeester K, van Hemert-Kluitenberg F, Moormann RJ, Dekker A. Comparison of test methodologies for foot-and-mouth disease virus serotype A vaccine matching. Clin Vaccine Immunol. (2014) 21:674-83. doi: $10.1128 /$ cvi.00034-14 
100. Paiba GA, Anderson J, Paton DJ, Soldan AW, Alexandersen S, Corteyn $\mathrm{M}$, et al. Validation of a foot-and-mouth disease antibody screening solidphase competition ELISA (SPCE). J Virol Methods. (2004) 115:145-58. doi: 10.1016/j.jviromet.2003.09.016

101. Valarcher JF, Leforban Y, Rweyemamu M, Roeder PL, Gerbier G, Mackay DK, et al. Incursions of foot-and-mouth disease virus into Europe between 1985 and 2006. Transbound Emerg Dis. (2008) 55:14-34. doi: 10.1111/j.1865-1682.2007.01010.x

102. Sangar DV, Black DN, Rowlands DJ, Brown F. Biochemical mapping of the foot-and-mouth disease virus genome. J Gen Virol. (1977) 35:281-97. doi: 10.1099/0022-1317-35-2-281

103. Cao Y, Lu Z, Li D, Fan P, Sun P, Bao H, et al. Evaluation of cross-protection against three topotypes of serotype $\mathrm{O}$ foot-and-mouth disease virus in pigs vaccinated with multi-epitope protein vaccine incorporated with poly(I:C). Vet Microbiol. (2014) 168:294-301. doi: 10.1016/j.vetmic.2013.11.023

104. van Maanen C. A complex-trapping-blocking (CTB) ELISA, using monoclonal antibodies and detecting specifically antibodies directed against foot-and-mouth disease types A, O and C. I. Method and characteristics. Vet Microbiol. (1990) 24:171-8.

105. Smitsaar EN, Saiz JC, Yedloutschnig RJ, Morgan DO. Detection of foot-andmouth disease virus by competitive ELISA using a monoclonal antibody specific for the $12 \mathrm{~S}$ protein subunit from six of the seven serotypes. Vet Immunol Immunopathol. (1990) 26:251-65.

106. Samuel AR, Knowles NJ, Samuel GD, Crowther JR. Evaluation of a trapping ELISA for the differentiation of foot-and-mouth disease virus strains using monoclonal antibodies. Biologicals. (1991) 19:299-310.

107. Smitsaart EN, Fernandez E, Maradei E, Morgan DO. Validation of an inhibition ELISA using a monoclonal antibody for foot-and-mouth disease (FMD) primary diagnosis. Zentralbl Veterinarmed B. (1994) 41:313-9.

108. Tosh C, Venkataramanan R, Pattnaik B, Hemadri D, Sanyal A. Monoclonal antibodies to an Indian strain of type A foot-and-mouth disease virus. Acta Virol. (1999) 43:219-25.

109. Morioka K, Fukai K, Yoshida K, Yamazoe R, Onozato H, Ohashi S, et al. Footand-mouth disease virus antigen detection enzyme-linked immunosorbent assay using multiserotype-reactive monoclonal antibodies. J Clin Microbiol. (2009) 47:3663-8. doi: 10.1128/jcm.00695-09

110. Holliger P, Hudson PJ. Engineered antibody fragments and the rise of single domains. Nat Biotechnol. (2005) 23:1126-36. doi: 10.1038/nbt1142

111. de Marco A. Biotechnological applications of recombinant singledomain antibody fragments. Microb Cell Fact. (2011) 10:44. doi: 10.1186/1475-2859-10-44

112. McCullough KC, De Simone F, Brocchi E, Capucci L, Crowther JR, Kihm U. Protective immune response against foot-and-mouth disease. J Virol. (1992) 66:1835-40.

113. Grubman MJ, Lewis SA, Morgan DO. Protection of swine against foot-andmouth disease with viral capsid proteins expressed in heterologous systems. Vaccine. (1993) 11:825-9.

114. MackayDK, Forsyth MA, Davies PR, Salt JS.. Antibody to the nonstructural proteins of foot-and-mouth disease virus in vaccinated animals exposed to infection. Vet Q. (1998) 20(Suppl. 2):S9-11.

115. Paton DJ, de Clercq K, Greiner M, Dekker A, Brocchi E, Bergmann I, et al. Application of non-structural protein antibody tests in substantiating freedom from foot-and-mouth disease virus infection after emergency vaccination of cattle. Vaccine. (2006) 24:6503-12. doi: 10.1016/j.vaccine.2006.06.032

116. De Diego M, Brocchi E, Mackay D, De Simone F. The non-structural polyprotein $3 \mathrm{ABC}$ of foot-and-mouth disease virus as a diagnostic antigen in ELISA to differentiate infected from vaccinated cattle. Arch Virol. (1997) 142:2021-33.

117. Bronsvoort BM, Sorensen KJ, Anderson J, Corteyn A, Tanya VN, Kitching $\mathrm{RP}$, et al. Comparison of two 3ABC enzyme-linked immunosorbent assays for diagnosis of multiple-serotype foot-and-mouth disease in a cattle population in an area of endemicity. J Clin Microbiol. (2004) 42:2108-14. doi: $10.1128 / \mathrm{jcm} .42 .5 .2108-2114.2004$

118. Bruderer U, Swam H, Haas B, Visser N, Brocchi E, Grazioli S, et al. Differentiating infection from vaccination in foot-and-mouth-disease: evaluation of an ELISA based on recombinant 3ABC. Vet Microbiol. (2004) 101:187-97. doi: 10.1016/j.vetmic.2004.01.021
119. Clavijo A, Zhou EM, Hole K, Galic B, Kitching P. Development and use of a biotinylated $3 \mathrm{ABC}$ recombinant protein in a solid-phase competitive ELISA for the detection of antibodies against foot-and-mouth disease virus. J Virol Methods. (2004) 120:217-27. doi: 10.1016/j.jviromet.2004.05.007

120. Moonen P, van der Linde E, Chenard G, Dekker A. Comparable sensitivity and specificity in three commercially available ELISAs to differentiate between cattle infected with or vaccinated against foot-and-mouth disease virus. Vet Microbiol. (2004) 99:93-101. doi: 10.1016/j.vetmic.2003.12.003

121. Armstrong RM, Cox SJ, Aggarwal N, Mackay DJ, Davies PR, Hamblin PA, et al. Detection of antibody to the foot-and-mouth disease virus (FMDV) non-structural polyprotein 3ABC in sheep by ELISA. J Virol Methods. (2005) 125:153-63. doi: 10.1016/j.jviromet.2005.01.012

122. Foord AJ, Muller JD, Yu M, Wang LF, Heine HG. Production and application of recombinant antibodies to foot-and-mouth disease virus non-structural protein 3ABC. J Immunol Methods. (2007) 321:142-51. doi: 10.1016/j.jim.2007.01.014

123. Lu Z, Cao Y, Guo J, Qi S, Li D, Zhang Q, et al. Development and validation of a $3 \mathrm{ABC}$ indirect ELISA for differentiation of foot-and-mouth disease virus infected from vaccinated animals. Vet Microbiol. (2007) 125:157-69. doi: 10.1016/j.vetmic.2007.05.017

124. Bronsvoort BMDC, Parida S, Handel I, McFarland S, Fleming L, Hamblin $\mathrm{P}$, et al. Serological survey for foot-and-mouth disease virus in wildlife in eastern Africa and estimation of test parameters of a nonstructural protein enzyme-linked immunosorbent assay for buffalo. Clin Vaccine Immunol. (2008) 15:1003-11. doi: 10.1128/CVI.00409-07

125. Ayebazibwe C, Mwiine FN, Balinda SN, Tjornehoj K, Alexandersen S. Application of the Ceditest(R) FMDV type $\mathrm{O}$ and FMDV-NS enzyme-linked immunosorbent assays for detection of antibodies against Foot-and-mouth disease virus in selected livestock and wildlife species in Uganda. J Vet Diagn Invest. (2012) 24:270-6. doi: 10.1177/1040638711435807

126. Mackay DKJ, Forsyth MA, Davies PR, Berlinzani A, Belsham GJ, Flint M, et al. Differentiating infection from vaccination in foot-and-mouth disease using a panel of recombinant, non-structural proteins in ELISA. Vaccine. (1998) 16:446-59. doi: 10.1016/S0264-410X(97)00227-2

127. McVicar JW, Sutmoller P. Foot-and-mouth disease: the agar gel diffusion precipitin test for antibody to virus-infection-associated (via) antigen as a tool for epizootiologic surveys1. Am J Epidemiol. (1970) 92:273-8. doi: 10.1093/oxfordjournals.aje.a121207

128. Alonso A, Gomes MPD, Martins MA, Sondahl MS. Detection of foot-andmouth disease virus infection-associated antigen antibodies: comparison of the enzyme-linked immunosorbent assay and agar gel immunodiffusion tests. Prev Vet Med. (1990) 9:223-40. doi: 10.1016/0167-5877(90) 90069-T

129. O’Donnell VK, Boyle DB, Sproat K, Fondevila NA, Forman A, Schudel $A A$, et al. Detection of antibodies against foot-and-mouth disease virus using a liquid-phase blocking sandwich ELISA (LPBE) with a bioengineered 3D protein. J Vet Diagn Invest. (1996) 8:143-50. doi: $10.1177 / 104063879600800201$

130. Sørensen KJ, Madsen KG, Madsen ES, Salt JS, Nqindi J, Mackay DKJ. Differentiation of infection from vaccination in foot-and-mouth disease by the detection of antibodies to the non-structural proteins $3 \mathrm{D}, 3 \mathrm{AB}$ and 3ABC in ELISA using antigens expressed in baculovirus. Arch Virol. (1998) 143:1461-76. doi: 10.1007/s007050050390

131. Hema M, Nagendrakumar SB, Yamini R, Chandran D, Rajendra L, Thiagarajan D, et al. Chimeric tymovirus-like particles displaying footand-mouth disease virus non-structural protein epitopes and its use for detection of FMDV-NSP antibodies. Vaccine. (2007) 25:4784-94. doi: 10.1016/j.vaccine.2007.04.023

132. Liu Z, Shao J, Zhao F, Zhou G, Gao S, Liu W, et al. Chemiluminescence immunoassay for the detection of antibodies against the $2 \mathrm{C}$ and $3 \mathrm{ABC}$ nonstructural proteins induced by infecting pigs with footand-mouth disease virus. Clin. Vaccine Immunol. (2017) 24:e00153-17. doi: 10.1128/cvi.00153-17

133. Liu ZZ, Zhao FR. Development of a chemiluminescence immunoassay using recombinant non-structural epitope-based proteins to accurately differentiate foot-and-mouth disease virus-infected and vaccinated bovines. Transbound Emerg Dis. (2018) 65:338-44. doi: 10.1111/tbed. 12811 
134. Brocchi E, Bergmann IE, Dekker A, Paton DJ, Sammin DJ, Greiner M, et al. Comparative evaluation of six ELISAs for the detection of antibodies to the non-structural proteins of foot-and-mouth disease virus. Vaccine. (2006) 24:6966-79. doi: 10.1016/j.vaccine.2006.04.050

135. Lee F, Jong M-H, Yang D-W. Presence of antibodies to non-structural proteins of foot-and-mouth disease virus in repeatedly vaccinated cattle. Vet Microbiol. (2006) 115:14-20. doi: 10.1016/j.vetmic.2005.12.017

136. Henderson LM. Overview of marker vaccine and differential diagnostic test technology. Biologicals. (2005) 33:203-9. doi: 10.1016/j.biologicals.2005.08.006

137. Li P, Lu Z, Bai X, Li D, Sun P, Bao H, et al. Evaluation of a 3A-truncated footand-mouth disease virus in pigs for its potential as a marker vaccine. Vet Res. (2014) 45:51. doi: 10.1186/1297-9716-45-51

138. Grubman MJ. Development of novel strategies to control foot-and-mouth disease: marker vaccines and antivirals. Biologicals. (2005) 33:227-34. doi: 10.1016/j.biologicals.2005.08.009

139. Rieder E, Baxt B, Lubroth J, Mason PW. Vaccines prepared from chimeras of foot-and-mouth disease virus (FMDV) induce neutralizing antibodies and protective immunity to multiple serotypes of FMDV. J Virol. (1994) 68:709298.

140. Taboga O, Tami C, Carrillo E, Núñez JI, Rodríguez A, Saíz JC, et al. A large-scale evaluation of peptide vaccines against foot-and-mouth disease: lack of solid protection in cattle and isolation of escape mutants. J Virol. (1997) 71:2606-14.

141. Knight-Jones TJ, Robinson L, Charleston B, Rodriguez LL, Gay CG, Sumption KJ, et al. Global foot-and-mouth disease research update and gap analysis: 4 - diagnostics. Transbound Emerg Dis. (2016) 63(Suppl. 1):42-8. doi: $10.1111 /$ tbed.12523

142. Lau LT, Reid SM, King DP, Lau AM, Shaw AE, Ferris NP, et al. Detection of foot-and-mouth disease virus by nucleic acid sequencebased amplification (NASBA). Vet Microbiol. (2008) 126:101-10. doi: 10.1016/j.vetmic.2007.07.008

143. Alvarez I, Gutierrez G, Barrandeguy M, Trono K. Immunochromatographic lateral flow test for detection of antibodies to Equine infectious anemia virus. J Virol Methods. (2010) 167:152-7. doi: 10.1016/j.jviromet.2010.03.026

144. Jiang T, Liang Z, Ren W, Chen J, Zhi X, Qi G, et al. Development and validation of a lateral flow immunoassay using colloidal gold for the identification of serotype-specific foot-and-mouth disease virus O, A and Asia 1. J Virol Methods. (2011) 171:74-80. doi: 10.1016/j.jviromet.2010.10.002

145. Jiang T, Liang Z, Ren WW, Chen J, Zhi XY, Qi GY, et al. A simple and rapid colloidal gold-based immunochromatogarpic strip test for detection of FMDV serotype A. Virol Sin. (2011) 26:30-9. doi: 10.1007/s12250-011-3166-5

146. Oem JK, Ferris NP, Lee K-N, Joo Y-S, Hyun B-H, Park J-H. Simple and rapid lateral-flow assay for the detection of foot-and-mouth disease virus. Clin Vaccine Immunol. (2009) 16:1660. doi: 10.1128/CVI.00213-09

147. Ferris NP, Nordengrahn A, Hutchings GH, Paton DJ, Kristersson T, Brocchi E, et al. Development and laboratory validation of a lateral flow device for the detection of serotype SAT 2 foot-and-mouth disease viruses in clinical samples. J Virol Methods. (2010) 163:474-6. doi: 10.1016/j.jviromet.2009.09.022

148. Chen TH, Pan CH, Jong MH, Lin HM, Huang YL, Hsiung KP, et al. Development of a chromatographic strip assay for detection of porcine antibodies to $3 \mathrm{ABC}$ non-structural protein of foot-and-mouth disease virus serotype O. J Vet Med Sci. (2009) 71:703-8. doi: 10.1292/jvms.71.703

149. Yang S, Yang J, Zhang G, Wang X, Qiao S, Zhao D, et al. Development of an immunochromatographic strip for the detection of antibodies against footand-mouth disease virus serotype O. J Virol Methods. (2010) 165:139-44. doi: 10.1016/j.jviromet.2010.01.001

150. Lin T, Shao JJ, Du JZ, Cong GZ, Gao SD, Chang H. Development of a serotype colloidal gold strip using monoclonal antibody for rapid detection type Asial foot-and-mouth disease. Virol J. (2011) 8:418. doi: 10.1186/1743-422X-8-418

151. Yang M, Caterer NR, Xu W, Goolia M. Development of a multiplex lateral flow strip test for foot-and-mouth disease virus detection using monoclonal antibodies. J Virol Methods. (2015) 221:119-26. doi: 10.1016/j.jviromet.2015.05.001
152. Wu L, Jiang T, Lu Z-J, Yang Y-M, Sun P, Liang Z, et al. Development and validation of a prokaryotically expressed foot-and-mouth disease virus non-structural protein 2C'3AB-based immunochromatographic strip to differentiate between infected and vaccinated animals. Virol J. (2011) 8:186. doi: 10.1186/1743-422X-8-186

153. Yang M, Goolia M, Xu W, Bittner H, Clavijo A. Development of a quick and simple detection methodology for foot-and-mouth disease virus serotypes O, A and Asia 1 using a generic RapidAssay Device. Virol J. (2013) 10:125. doi: 10.1186/1743-422X-10-125

154. Morioka K, Fukai K, Yoshida K, Kitano R, Yamazoe R, Yamada M, et al. Development and evaluation of a rapid antigen detection and serotyping lateral flow antigen detection system for foot-and-mouth disease virus. PLoS ONE. (2015) 10:e0134931. doi: 10.1371/journal.pone.0134931

155. Wang H, Hou P, Zhao G, Yu L, Gao Y-W, He H. Development and evaluation of serotype-specific recombinase polymerase amplification combined with lateral flow dipstick assays for the diagnosis of foot-andmouth disease virus serotype A, O and Asial. BMC Vet Res. (2018) 14:359. doi: 10.1186/s12917-018-1644-4

156. Liu L, Wang J, Zhang R, Lin M, Shi R, Han Q, et al. Visual and equipmentfree reverse transcription recombinase polymerase amplification method for rapid detection of foot-and-mouth disease virus. BMC Vet Res. (2018) 14:263. doi: 10.1186/s12917-018-1594-x

157. Koczula KM, Gallotta A. Lateral flow assays. Essays Biochem. (2016) 60:11120. doi: 10.1042/EBC20150012

158. Sithigorngul P, Rukpratanporn S, Pecharaburanin N, Suksawat P, Longyant $\mathrm{S}$, Chaivisuthangkura $\mathrm{P}$, et al. A simple and rapid immunochromatographic test strip for detection of pathogenic isolates of Vibrio harveyi. J Microbiol Methods. (2007) 71:256-64. doi: 10.1016/j.mimet.2007.09.012

159. Cui S, Chen C, Tong G. A simple and rapid immunochromatographic strip test for monitoring antibodies to H5 subtype Avian Influenza Virus. J Virol Methods. (2008) 152:102-5. doi: 10.1016/j.jviromet.2008.06.011

160. Ferris NP, Clavijo A, Yang M, Velazquez-Salinas L, Nordengrahn A, Hutchings GH, et al. Development and laboratory evaluation of two lateral flow devices for the detection of vesicular stomatitis virus in clinical samples. J Virol Methods. (2012) 180:96-100. doi: 10.1016/j.jviromet.2011.12.010

161. Zhou SH, Cui SJ, Chen CM, Zhang FC, Li J, Zhou S, et al. Development and validation of an immunogold chromatographic test for on-farm detection of PRRSV. J Virol Methods. (2009) 160:178-84. doi: 10.1016/j.jviromet.2009.04.034

162. Zhang GP, Wang XN, Yang JF, Yang YY, Xing GX, Li QM, et al. Development of an immunochromatographic lateral flow test strip for detection of $\beta$ adrenergic agonist Clenbuterol residues. J Immunol Methods. (2006) 312:2733. doi: 10.1016/j.jim.2006.02.017

163. Zhao Y, Zhang G, Liu Q, Teng M, Yang J, Wang J. Development of a lateral flow colloidal gold immunoassay strip for the rapid detection of enrofloxacin residues. J Agric Food Chem. (2008) 56:12138-42. doi: 10.1021/jf802648z

164. Jiang T, Liang Z, Chen J, He JJ, Lu L, Ma WM, et al. [Establishment of a colloid gold-immunochromatography assay for detection of type Asia I footand-mouth disease virus]. Chinese J Cell Mol Immunol. (2007) 23:1021-4.

165. Reid SM, Ferris NP, Bruning A, Hutchings GH, Kowalska Z, Akerblom L. Development of a rapid chromatographic strip test for the pen-side detection of foot-and-mouth disease virus antigen. J Virol Methods. (2001) 96:189-202. doi: 10.1016/s0166-0934(01)00334-2

166. Ferris NP, Nordengrahn A, Hutchings GH, Reid SM, King DP, Ebert K, et al. Development and laboratory validation of a lateral flow device for the detection of foot-and-mouth disease virus in clinical samples. J Virol Methods. (2009) 155:10-7. doi: 10.1016/j.jviromet.2008.09.009

167. Sammin D, Ryan E, Ferris NP, King DP, Zientara S, Haas B, et al. Options for decentralized testing of suspected secondary outbreaks of foot-and-mouth disease. Transbound Emerg Dis. (2010) 57:237-43. doi: 10.1111/j.1865-1682.2010.01141.x

168. Jamal SM, Belsham GJ. Foot-and-mouth disease: past, present and future. Vet Res. (2013) 44:116. doi: 10.1186/1297-9716-44-116

169. Yang M, Clavijo A, Suarez-Banmann R, Avalo R. Production and characterization of two serotype independent monoclonal antibodies against foot-and-mouth disease virus. Vet Immunol Immunopathol. (2007) 115:12634. doi: 10.1016/j.vetimm.2006.10.002 
170. Maradei E, Perez Beascoechea C, Malirat V, Salgado G, Seki C, Pedemonte A, et al. Characterization of foot-and-mouth disease virus from outbreaks in Ecuador during 2009-2010 and cross-protection studies with the vaccine strain in use in the region. Vaccine. (2011) 29:8230-40. doi: 10.1016/j.vaccine.2011.08.120

171. Amada T, Yoshimatsu K, Koma T, Shimizu K, Gamage CD, Shiokawa K, et al. Development of an immunochromatography strip test based on truncated nucleocapsid antigens of three representative hantaviruses. Virol J. (2014) 11:87. doi: 10.1186/1743-422x-11-87

172. Zhuang L, Ji Y, Tian P, Wang K, Kou C, Gu N, et al. Polymerase chain reaction combined with fluorescent lateral flow immunoassay based on magnetic purification for rapid detection of canine parvovirus 2. BMC Vet Res. (2019) 15:30. doi: 10.1186/s12917-019-1774-3

173. Yan G, Jun L, Kangchen Z, Yiyue G, Yang Y, Xiaoyu Z, et al. Rapid and visual detection of human enterovirus coxsackievirus A16 by reverse transcription loop-mediated isothermal amplification combined with lateral flow device. Lett Appl Microbiol. (2015) 61:531-7. doi: 10.1111/lam.12499

174. Yang M, Ke Y, Wang X, Ren H, Liu W, Lu H, et al. Development and evaluation of a rapid and sensitive EBOV-RPA test for rapid diagnosis of Ebola virus disease. Sci Rep. (2016) 6:26943. doi: 10.1038/srep26943

175. Yang Y, Qin X, Song Y, Zhang W, Hu G, Dou Y, et al. Development of real-time and lateral flow strip reverse transcription recombinase polymerase Amplification assays for rapid detection of peste des petits ruminants virus. Virol J. (2017) 14:24. doi: 10.1186/s12985-017-0688-6

176. Sun N, Wang W, Wang J, Yao X, Chen F, Li X, et al. Reverse transcription recombinase polymerase amplification with lateral flow dipsticks for detection of influenza A virus and subtyping of $\mathrm{H} 1$ and H3. Mol Cell Probes. (2018) 42:25-31. doi: 10.1016/j.mcp.2018.10.004

177. Cheng S, Sun J, Yang J, Lv J, Wu F, Lin Y, et al. A new immunoassay of serum antibodies against Peste des petits ruminants virus using quantum dots and a lateral-flow test strip. Anal Bioanal Chem. (2017) 409:133-41. doi: 10.1007/s00216-016-9972-3

178. Wang H-M, Zhao G-M, Hou P-L, Yu L, He C-Q, He H-B. Rapid detection of foot-and-mouth disease virus using reverse transcription recombinase polymerase amplification combined with a lateral flow dipstick. J. Virol. Methods. (2018) 261:46-50. doi: 10.1016/j.jviromet.2018.07.011

179. Samuel AR, Knowles NJ. Foot-and-mouth disease type O viruses exhibit genetically and geographically distinct evolutionary lineages (topotypes). $J$ Gen Virol. (2001) 82(Pt 3):609-21. doi: 10.1099/0022-1317-82-3-609

180. Steinfeld $\mathrm{H}$, Wassenaar T, Jutzi S. Livestock production systems in developing countries: status, drivers, trends. Rev Sci Tech. (2006) 25:505-16. doi: $10.20506 /$ rst.25.2.1677
181. FAO. The State of Food Security and Nutrition in the World 2019 [Online]. (2019). Available online at: http://www.fao.org/state-of-foodsecurity-nutrition/en/ (accessed June 14, 2020).

182. FAO. Preparation of Foot-and-Mouth Disease Contigency Plans: Early Warning Contingency Planning for FMD [Online] (2002). Available online at: http://www.fao.org/3/Y4382E/y4382e08.htm\#bm08 (accessed June 14, 2020).

183. Paton DJ, Sumption KJ, Charleston B. Options for control of foot-and-mouth disease: knowledge, capability and policy. Philos Trans R Soc Lond Ser B Biol Sci. (2009) 364:2657-67. doi: 10.1098/rstb.2009.0100

184. Madi M, Hamilton A, Squirrell D, Mioulet V, Evans P, Lee M, et al. Rapid detection of foot-and-mouth disease virus using a field-portable nucleic acid extraction and real-time PCR amplification platform. Vet J. (2012) 193:67-72. doi: 10.1016/j.tvjl.2011.10.017

185. Knight-Jones TJ, Robinson L, Charleston B, Rodriguez LL, Gay CG, Sumption KJ, et al. Global foot-and-mouth disease research update and gap analysis: 1 - Overview of global status and research needs. Transbound Emerg Dis. (2016) 63(Suppl. 1):3-13. doi: 10.1111/tbed.12528

186. Gao M, Zhang R, Li M, Li S, Cao Y, Ma B, et al. An ELISA based on the repeated foot-and-mouth disease virus $3 \mathrm{~B}$ epitope peptide can distinguish infected and vaccinated cattle. Appl Microbiol Biotechnol. (2012) 93:1271-9. doi: 10.1007/s00253-011-3815-0

187. Sharma GK, Mohapatra JK, Pandey LK, Mahajan S, Mathapati BS, Sanyal $A$, et al. Immunodiagnosis of foot-and-mouth disease using mutated recombinant $3 \mathrm{ABC}$ polyprotein in a competitive ELISA. J Virol Methods. (2012) 185:52-60. doi: 10.1016/j.jviromet.2012.05.029

188. Paton DJ, Ferris NP, Hutchings GH, Li Y, Swabey K, Keel P, et al. Investigations into the cause of foot-and-mouth disease virus seropositive small ruminants in Cyprus during 2007. Transbound Emerg Dis. (2009) 56:321-8. doi: 10.1111/j.1865-1682.2009.01088.x

Conflict of Interest: The authors declare that the research was conducted in the absence of any commercial or financial relationships that could be construed as a potential conflict of interest.

Copyright (c) 2020 Wong, Yong, Ong, Ho and Tan. This is an open-access article distributed under the terms of the Creative Commons Attribution License (CC BY). The use, distribution or reproduction in other forums is permitted, provided the original author(s) and the copyright owner(s) are credited and that the original publication in this journal is cited, in accordance with accepted academic practice. No use, distribution or reproduction is permitted which does not comply with these terms. 